\title{
Constraints on source-forming processes of West Greenland kimberlites inferred from $\mathrm{Hf}-\mathrm{Nd}$ isotope systematics
}

\author{
Amy M. Gaffney ${ }^{\mathrm{a}, *}$, Janne Blichert-Toft ${ }^{\mathrm{b}}$, Bruce K. Nelson ${ }^{\mathrm{a}}$, Martin Bizzarro ${ }^{\mathrm{c}}$, \\ Minik Rosing ${ }^{\mathrm{d}}$, Francis Albarède ${ }^{\mathrm{b}}$ \\ a Department of Earth and Space Sciences, Box 351310, University of Washington, Seattle, WA 98195, USA \\ ${ }^{\mathrm{b}}$ Laboratoire de Sciences de la Terre, CNRS UMR 5570, Ecole Normale Supérieure de Lyon, 46, Allée d'Italie, 69364 Lyon Cedex 7, France \\ ${ }^{\mathrm{c}}$ Geological Institute, University of Copenhagen, Oster Volgade 10, DK-1350 Copenhagen, Denmark \\ ${ }^{\mathrm{d}}$ Nordic Center for Earth Evolution (NordCEE), Natural History Museum of Denmark, Øster Volgade 5-7, DK-1350 Copenhagen K, Denmark
}

Received 5 June 2006; accepted in revised form 6 March 2007; available online 24 March 2007

\begin{abstract}
Kimberlites from West Greenland have $\mathrm{Hf}-\mathrm{Nd}$ isotope as well as major and trace element compositions that are similar to other Group I kimberlites, but that are distinctive in the spectrum of magmas sampled at Earth's surface. The West Greenland kimberlites have $\varepsilon_{\mathrm{Ndi}}$ that ranges from +1.6 to +3.1 and $\varepsilon_{\mathrm{Hfi}}$ that ranges from -4.3 to +4.9 . The samples exhibit ubiquitous negative $\Delta \varepsilon_{\mathrm{Hfi}}$ (deviation from the ocean island basalt $\varepsilon_{\mathrm{Hf}}-\varepsilon_{\mathrm{Nd}}$ reference line), ranging from -1.8 to -11.2 . The kimberlites are characterized by steep heavy rare earth element patterns, positive $\mathrm{Ta}-\mathrm{Nb}$ anomalies and negative $\mathrm{Hf}-\mathrm{Zr}$ anomalies. These chemical signals are consistent with the presence of ancient, subducted oceanic crust in the kimberlite source region. In the model we present, dewatering and possibly partial melting of rutilebearing oceanic crust during subduction results in characteristic trace element patterns in the residual crust. During aging, the $\mathrm{Hf}-\mathrm{Nd}$ isotopic composition of this dewatered/partially melted EMORB-type crust evolves to negative $\Delta \varepsilon_{\mathrm{Hfi}}$ values. Metasomatic fluids derived from this ancient subducted oceanic crust infiltrate and impart their trace element and isotopic signal on proximal peridotitic mantle. Melting of this metasomatized mantle peridotite results in kimberlite magmas.
\end{abstract}

(c) 2007 Elsevier Ltd. All rights reserved.

\section{INTRODUCTION}

Kimberlites erupt exclusively through ancient continental crust (Archean cratons and Proterozoic mobile belts) and are inferred to originate at great depths in the mantle. Because of this, kimberlites may uniquely sample mantle source(s) that are not otherwise evident in continental or oceanic magmatism. Kimberlites are classified into groups based on petrographic and isotopic characteristics. 'Group I' kimberlites have $\mathrm{Sr}-\mathrm{Nd}-\mathrm{Pb}$ isotopic characteristics simi-

\footnotetext{
* Corresponding author. Address: Lawrence Livermore National Laboratory, Chemistry, Materials and Life Sciences Directorate, 7000 East Avenue L-231, Livermore, CA 94550, USA.

E-mail address: gaffney1@1lnl.gov (A.M. Gaffney).
}

lar to those of ocean island basalts (OIB); these are described as 'basaltic' on a petrographic basis (Dawson, 1967; Smith, 1983). In contrast, 'Group II' kimberlites, which contain abundant phlogopite and therefore are described as 'micaceous', have $\mathrm{Sr}$ and $\mathrm{Nd}$ isotope compositions that indicate long-term incompatible element enrichment in the mantle source (Dawson, 1967; Smith, 1983). 'Transitional' kimberlites have isotopic compositions that fall between those of Group I and Group II. A wide range of sources have been proposed for Group I kimberlite magmas, including sub-continental lithospheric mantle (SCLM) (e.g., le Roex et al., 2003; Becker and le Roex, 2006 and references therein), upper mantle (e.g., Smith, 1983), lower mantle (e.g., Haggerty, 1994), and ancient subducted oceanic crust (e.g., Sharp, 1974; Ringwood et al., 1992; Nowell et al., 2004). 
Although Group I kimberlites have $\mathrm{Sr}-\mathrm{Nd}-\mathrm{Pb}$ isotope compositions that suggest an affinity to mantle sources sampled by OIBs, their major and trace element compositions, as well as high volatile contents, present a point of contrast to OIBs (e.g., Smith, 1983; Mitchell, 1995). Furthermore, recent studies of $\mathrm{Hf}-\mathrm{Nd}$ isotope compositions show that some Group I kimberlites fall below the mantle $\varepsilon_{\mathrm{Nd}}-\varepsilon_{\mathrm{Hf}}$ array as defined by the composition of OIBs erupted globally (Bizzarro et al., 2002; Schmidberger et al., 2002; Nowell et al., 2004). However, the $\varepsilon_{\mathrm{Nd}}-\varepsilon_{\mathrm{Hf}}$ array of crustal and mantle-derived rocks falls above the composition of bulk silicate Earth as determined from chondrites, and this observation has been used to infer the existence below the mantle array of a 'missing mantle reservoir' necessary to provide closure in the $\varepsilon_{\mathrm{Nd}}-\varepsilon_{\mathrm{Hf}}$ mass balance of bulk silicate Earth (Blichert-Toft and Albarède, 1997). Because of the distinctive Hf-Nd isotopic characteristics of kimberlites, the existence of a component similar to the source of kimberlites and associated alkalic magmas has been proposed as a possible solution (Bizzarro et al., 2002; Janney et al., 2002; Nowell et al., 2004) to the issue of a 'missing mantle reservoir' (Blichert-Toft and Albarède, 1997). However, this proposed solution assumes that the properties of the few so-far analyzed kimberlite samples represent those of a prevalent deep mantle component. If the kimberlite mantle source is in fact the 'missing reservoir', then it is important to understand its entire geographic extent, as well as the range of time over which it was sampled, to fully determine the processes by which this reservoir forms.

To address these questions, we have undertaken a Hf$\mathrm{Nd}$ isotope, and major and trace element study of $\sim 600 \mathrm{Ma}$ kimberlites from the Sarfartoq region of West Greenland (Larsen et al., 1983; Scott Smith, 1987; Nelson, 1989; Larsen and Rex, 1992; Bizzarro et al., 2002). This region was recently deglaciated, and as a result, the kimberlite samples are remarkably fresh given their age. The kimberlites erupted on the edge of the Archean craton, and in the Proterozoic Nagssugtoqidian mobile belt, and therefore provide the possibility of evaluating variability in the kimberlite sources relative to the tectonic province. The West Greenland kimberlites provide the opportunity for comparison with other kimberlite occurrences of various ages in South Africa and Canada, and therefore also allow us to compare characteristics of kimberlite source regions through time and over a wide geographic region. Lastly, we discuss the implications of our results and interpretations of kimberlite source regions in terms of the $\varepsilon_{\mathrm{Nd}}-\varepsilon_{\mathrm{Hf}}$ mass balance of bulk silicate Earth.

\section{ANALYTICAL PROCEDURES}

Samples for all analyses were rough-crushed with a stainless steel mortar and pestle. Chips free of visible alteration and identifiable xenolithic inclusions were picked for isotopic analysis and powdered with an agate mortar and pestle. Samples were digested at the Ecole Normale Supérieure in Lyon (ENSL). Powders were spiked from the outset with mixed ${ }^{176} \mathrm{Lu}-{ }^{180} \mathrm{Hf}$ and ${ }^{147} \mathrm{Sm}-{ }^{150} \mathrm{Nd}$ tracer solutions and dissolved in a $\sim 10: 1$ mixture of concentrated $\mathrm{HF}-$
$\mathrm{HNO}_{3}$ using steel-jacketed Teflon bombs placed in an oven for one week at $155^{\circ} \mathrm{C}$. Prior to final dissolution and achievement of sample-spike equilibration in $6 \mathrm{M} \mathrm{HCl}$, samples were fumed with $\mathrm{HClO}_{4}$ to decompose fluorides. The perchlorates were subsequently driven off by $6 \mathrm{M}$ $\mathrm{HCl}$. Lutetium and $\mathrm{Hf}$ were separated at ENSL as described by Blichert-Toft et al. $(1997,2002)$ and BlichertToft (2001), and the light rare earth element (LREE) fractions recovered from the $\mathrm{Lu}-\mathrm{Hf}$ separation protocol were processed further at University of Washington (UW) for $\mathrm{Sm}$ and $\mathrm{Nd}$ purification. Separation of $\mathrm{Nd}$ and $\mathrm{Sm}$ from the LREE fractions was carried out on columns with HDEHP-coated teflon beads using $0.14 \mathrm{~N}$ and $0.5 \mathrm{~N} \mathrm{HCl}$ eluants.

Isotopic analyses of $\mathrm{Hf}$ and $\mathrm{Lu}$ were carried out on the VG Plasma 54 MC-ICP-MS at ENSL following the procedures of Blichert-Toft et al. (1997) for Hf and Blichert-Toft et al. (2002) for Lu. ${ }^{176} \mathrm{Hf} /{ }^{177} \mathrm{Hf}$ was normalized for instrumental mass fractionation relative to ${ }^{179} \mathrm{Hf} /{ }^{177} \mathrm{Hf}=0.7325$ using an exponential law. The JMC-475 Hf standard gave ${ }^{176} \mathrm{Hf} /{ }^{177} \mathrm{Hf}=0.282160 \pm 0.000010(2 \sigma)$ (i.e., a reproducibility of $35 \mathrm{ppm}$ ) during the single run session of the present samples and was measured systematically every second sample to monitor instrument performance.

Isotopic analyses of $\mathrm{Sm}$ and $\mathrm{Nd}$ were conducted at the University of Washington on a $\mathrm{Nu}$ Instruments MC-ICPMS. A detailed protocol for these analyses at UW has not been published previously, so we present the protocol here. Measured Nd isotope ratios were corrected for instrumental mass fractionation using an exponential law and ${ }^{146} \mathrm{Nd} /{ }^{144} \mathrm{Nd}=0.7219$. Neodymium isotope analyses of samples were bracketed with analyses of the laboratory standard (Ames metal) and all sample analyses completed in a day were normalized to the daily average standard value. During any daily session, the reproducibility of the standard was 32-39 ppm (2 $\sigma)$, and between all daily sessions the maximum variability among the daily means was $24 \mathrm{ppm}$. Normalization was done by comparing the measured value of the Ames metal to that measured by thermal ionization mass spectrometry (VG Sector TIMS, see Nelson (1995) for analytical details). The Ames metal standard was tied to the La Jolla Nd standard by a series of measurements on both TIMS and MC-ICP-MS. The average La Jolla $\mathrm{Nd}$ measured by TIMS at UW is ${ }^{143} \mathrm{Nd} /{ }^{144} \mathrm{Nd}=0.511843 \pm 0.000016 \quad(2 \sigma=32 \mathrm{ppm} ; \quad n=$ 93). The average La Jolla Nd measured by MC-ICP-MS is ${ }^{143} \mathrm{Nd} /{ }^{144} \mathrm{Nd}=0.511844 \pm 0.000020(2 \sigma=40 \mathrm{ppm} ; n=$ 12) when normalized to the same Ames metal isotope composition. Both TIMS and MC-ICP-MS yield the same isotopic offset between the La Jolla standard and the Ames metal lab standard. The Nd isotope composition of samples is calculated from the spiked sample by an iterative process of spike subtraction. We monitor the ${ }^{145} \mathrm{Nd} /{ }^{144} \mathrm{Nd}$ of the samples both as an additional check of accuracy, and to verify the spike subtraction procedure. For all the samples reported here, the average ${ }^{145} \mathrm{Nd} /{ }^{144} \mathrm{Nd}=0.348406 \pm$ 0.000011 , which is within $32 \mathrm{ppm}$ of the accepted value of 0.348417 . Interference from ${ }^{144} \mathrm{Sm}$ was measured on mass 147. In all cases corrections to ${ }^{144} \mathrm{Nd}$ were less than $14 \mathrm{ppm}$, and typically less than $10 \mathrm{ppm}$. Sample analyte 
concentrations (in $0.2 \mathrm{~N} \mathrm{HNO}_{3}$ ) were adjusted so that sample ion beam intensities were within $15 \%$ of that observed for the standard. Samarium and $\mathrm{Nd}$ concentrations were determined on samples spiked with enriched isotopes calibrated to Ames $\mathrm{Nd}$ and $\mathrm{Sm}$ ultrapure metal gravimetric standards. Errors in concentration are $<0.5 \%$.

Major (XRF) and trace element (ICP-MS) analyses were completed at the Washington State University GeoAnalytical lab, according to procedures given in Johnson et al. (1999), and on the facility website (http://www.wsu.edu/ $\sim$ geolab/). With only a few exceptions, noted on Table 2 , major element concentrations in the samples did not exceed concentrations in the standards by more than $20 \%$. Analytical precision $(2 \sigma)$ is based upon repeat analyses of the BCR-P standard, and is within $0.8 \%$ for major elements except for $\mathrm{MgO}(2.8 \%)$, $\mathrm{MnO}(2.1 \%)$ and $\mathrm{Na}_{2} \mathrm{O}(6 \%)$ (Johnson et al., 1999). For ICP-MS trace element analyses, precision is typically within $6 \%(2 \sigma)$. Repeat analyses of the present kimberlite samples were all well within the limits of these quoted uncertainties. Several elements were analyzed by both XRF and ICP-MS (Ba, Rb, Sr, Zr, Y, Nb, $\mathrm{Pb}, \mathrm{La}, \mathrm{Ce}, \mathrm{Th})$. Although the XRF analyses of these elements were included in the normalization of the XRF data presented in Table 2 and plotted in the figures (major elements + trace elements + LOI $=100 \%$ ), only the ICP-MS analyses of these elements are listed in Table 2. All plots of trace element data include only ICP-MS results.

\section{RESULTS}

\subsection{Field relations and sample description}

Kimberlites and associated carbonatites in the Sarfartoq region of West Greenland erupted at $\sim 600 \mathrm{Ma}$ (Scott, 1981 ; Larsen et al., 1983; Larsen and Rex, 1992; Bizzarro et al., 2002). The kimberlites studied here erupted through the Archean craton as well as the Proterozoic Nagssugtoqidian Orogen, which constitutes reworked Archean cratonic material (van Gool et al., 2002). In the field, the kimberlites are exposed as dark gray loose boulders or dikes. They appear exceptionally fresh in hand sample, reflecting the recent deglaciation of the region. Sample locations are shown in Fig. 1 and listed in Table 1.

The West Greenland kimberlites are classified as Group I, on both a petrographic and isotopic basis. They are OIBlike in their $\mathrm{Nd}-\mathrm{Sr}-\mathrm{Pb}$ isotopic compositions (this study; Nelson, 1989), and though phlogopite is present in minor amounts in some samples, it is not a dominant constituent in all samples, as would be expected for Group II kimberlites. The dominant phenocryst phases in the studied kimberlites are olivine and ilmenite. It is likely that some of the samples contain accumulated olivine, as its modal abundance in some samples is up to $70 \%$. Olivine ranges from very fresh to serpentinized. Clinopyroxene and calcite are also present as minor phases. Although some of the kimber-

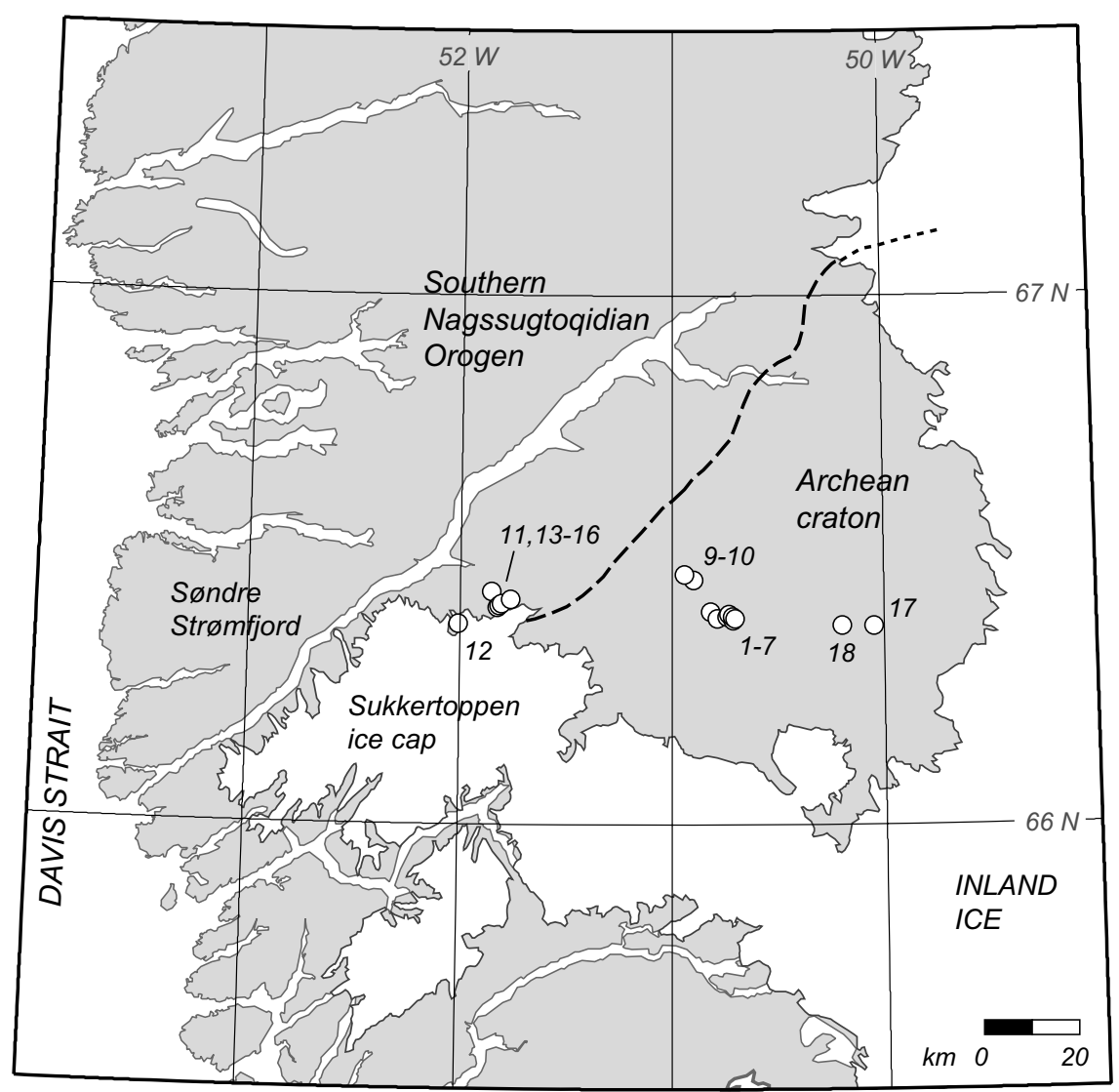

Fig. 1. Map of West Greenland, showing sample locations. Location of KIM 18 is approximate. Boundary between Archean craton and Southern Nagssugtoqidian Orogen from van Gool et al. (2002). 
Table 1

Sample locations

\begin{tabular}{llll}
\hline Sample & Latitude & Longitude & Location relative to craton \\
\hline KIM 1 & N $66^{\circ} 24^{\prime} 11^{\prime \prime}$ & W $50^{\circ} 49^{\prime} 09^{\prime \prime}$ & On \\
KIM 2 & N $66^{\circ} 23^{\prime} 25^{\prime \prime}$ & W $50^{\circ} 47^{\prime} 12^{\prime \prime}$ & On \\
KIM 3 & N $66^{\circ} 23^{\prime} 34^{\prime \prime}$ & W $50^{\circ} 44^{\prime} 27^{\prime \prime}$ & On \\
KIM 4 & N $66^{\circ} 23^{\prime} 53^{\prime \prime}$ & W $50^{\circ} 43^{\prime} 58^{\prime \prime}$ & On \\
KIM 5 & N $66^{\circ} 23^{\prime} 13^{\prime \prime}$ & W $50^{\circ} 42^{\prime} 42^{\prime \prime}$ & On \\
KIM 6 & N $66^{\circ} 23^{\prime} 36^{\prime \prime}$ & W $50^{\circ} 42^{\prime} 59^{\prime \prime}$ & On \\
KIM 7 & N $66^{\circ} 23^{\prime} 21^{\prime \prime}$ & W $50^{\circ} 42^{\prime} 12^{\prime \prime}$ & On \\
KIM 9 & N $66^{\circ} 27^{\prime} 45^{\prime \prime}$ & W $50^{\circ} 54^{\prime} 01^{\prime \prime}$ & On \\
KIM 10 & N $66^{\circ} 28^{\prime} 25^{\prime \prime}$ & W $51^{\circ} 49^{\prime} 33^{\prime \prime}$ & Off \\
KIM 11 & N $66^{\circ} 24^{\prime} 34^{\prime \prime}$ & W $51^{\circ} 58^{\prime} 33^{\prime \prime}$ & Off \\
KIM 12 & N $66^{\circ} 22^{\prime} 43^{\prime \prime}$ & W $51^{\circ} 51^{\prime} 07^{\prime \prime}$ & Off \\
KIM 13 & N $66^{\circ} 26^{\prime} 24^{\prime \prime}$ & W $51^{\circ} 48^{\prime} 59^{\prime \prime}$ & Off \\
KIM 14 & N $66^{\circ} 24^{\prime} 49^{\prime \prime}$ & W $51^{\circ} 48^{\prime} 26^{\prime \prime}$ & Off \\
KIM 15 & N $66^{\circ} 25^{\prime} 01^{\prime \prime}$ & W $55^{\circ} 46^{\prime \prime} 59^{\prime \prime}$ & Off \\
KIM 16 & N $66^{\circ} 25^{\prime} 32^{\prime \prime}$ & On \\
KIM 17 & N $66^{\circ} 22^{\prime} 33^{\prime \prime}$ & & \\
\hline
\end{tabular}

lite occurrences contain xenolithic nodules, the analyzed samples were examined to ascertain that they contain no visible xenolithic fragments, and thin sections of the kimberlites were also confirmed to be free of xenolithic fragments. The only petrographic evidence for possible contamination of the kimberlites is the abundant olivine present in some samples. Although accumulation of olivine would affect the major element composition of a sample, its only effect on the trace element compositions would be dilution, thus preserving the relative abundances of incompatible trace elements. Isotopically, there is also minimal evidence for contamination. The very high concentrations of $\mathrm{Nd}$ and $\mathrm{Hf}$ in the kimberlites reduce the magnitude of potential contamination effects. Because the Hf isotopic composition of SCLM, the principal potential contaminant, is very radiogenic with respect to the mantle-crust array, contamination of kimberlite magma by SCLM would impart a radiogenic $\mathrm{Hf}$ isotopic composition, relative to the $\mathrm{Nd}$ isotopic composition, on the kimberlite (Schmidberger et al., 2002). However, as discussed in a later section, the Hf isotopic compositions of our kimberlite samples are unradiogenic relative to their $\mathrm{Nd}$ isotopic compositions. Although it is not possible to completely rule out a component of crustal contamination in these samples, the observations described above indicate that any contamination has not made a significant contribution to the isotope or trace element systematics of the kimberlites.

\subsection{Major elements}

The kimberlites as a whole are characterized by very low $\mathrm{SiO}_{2}(19-33 \mathrm{wt} \%)$ and very high $\mathrm{MgO}(18-34 \mathrm{wt} \%$, Fig. 2, Table 2). Alkalis are not well correlated with either $\mathrm{SiO}_{2}$ or $\mathrm{MgO}$, and range from 0.2 to $1.8 \mathrm{wt} \%$ $\left(\mathrm{K}_{2} \mathrm{O}+\mathrm{Na}_{2} \mathrm{O}\right)$. The samples also have high volatile contents, as inferred from carbonate veins observed in some samples, and as manifested by high loss-on-ignition (LOI, $10-20 \mathrm{wt} \%$ ). There is no apparent correlation between sample location and major element composition. $\mathrm{SiO}_{2}$ and $\mathrm{MgO}$ are well-correlated, and $\mathrm{SiO}_{2}$ also correlates well with
$\mathrm{CaO}$ and $\mathrm{P}_{2} \mathrm{O}_{5}$. Although olivine is the dominant phenocryst in these samples, ilmenite is present in some of the kimberlites, and this may account for their large variations in $\mathrm{TiO}_{2}$ contents $(1.7-4.3 \mathrm{wt} \%)$. The kimberlites analyzed in this study show a similar range in composition to other kimberlites from the region, as well as similar trends of compositional variation. Notable differences, which may be related to differing proportions of accumulated olivine and ilmenite, are that our suite of samples has slightly higher $\mathrm{SiO}_{2}$ and alkali contents, and slightly lower $\mathrm{MgO}$ and $\mathrm{TiO}_{2}$ contents relative to most other kimberlites from the region (Scott Smith, 1987; Larsen and Rex, 1992; Nielsen and Jensen, 2005).

\subsection{Trace elements}

The rare earth element (REE) patterns of the kimberlites show very strong enrichments in LREE relative to heavy (H)REE, and (La/Yb) $)_{\mathrm{N}} \sim 80-280$ (Fig. 3, Table 2). Spider diagrams of primitive mantle-normalized (Sun and McDonough, 1989) incompatible trace elements also show very strong enrichments in the most incompatible elements, and depletions in HREE, consistent with residual garnet in the magma source. Notable depletions in $\mathrm{K}, \mathrm{Sr}$, $\mathrm{Hf}$ and $\mathrm{Zr}$ are common in these samples (Fig. 4a) and contrast with enrichments in $\mathrm{Ta}$, and, to a lesser extent, $\mathrm{Nb}$. The trace element patterns are similar to those observed in kimberlites from West Greenland (Nielsen and Jensen, 2005; average composition shown in Fig. 4) as well as other regions (Namibia-Spriggs, 1988; Finland-O'Brien and Tyni, 1998; S. Africa-le Roex et al., 2003). Several samples lack distinctive $\mathrm{Hf}-\mathrm{Zr}$ depletions (Fig. 4b; primitive mantle-normalized ratios of $\mathrm{Sm} / \mathrm{Zr}, \mathrm{Sm} / \mathrm{Hf}>1.85$ is considered 'depletion'), but otherwise have trace element patterns similar to the rest of the kimberlites. Two samples show exceptions to these patterns (Fig. 4b). KIM 15 has no (or a slightly positive) $\mathrm{Hf}-\mathrm{Zr}$ anomaly, and no $\mathrm{Ta}-\mathrm{Nb}$ or $\mathrm{K}$ anomalies. KIM 17, which is geographically the most isolated sample, also shows no (or only a slightly positive) $\mathrm{Hf}-\mathrm{Zr}$ anomaly, as well as no $\mathrm{Sr}$ anomaly. There is no specific distinction in 

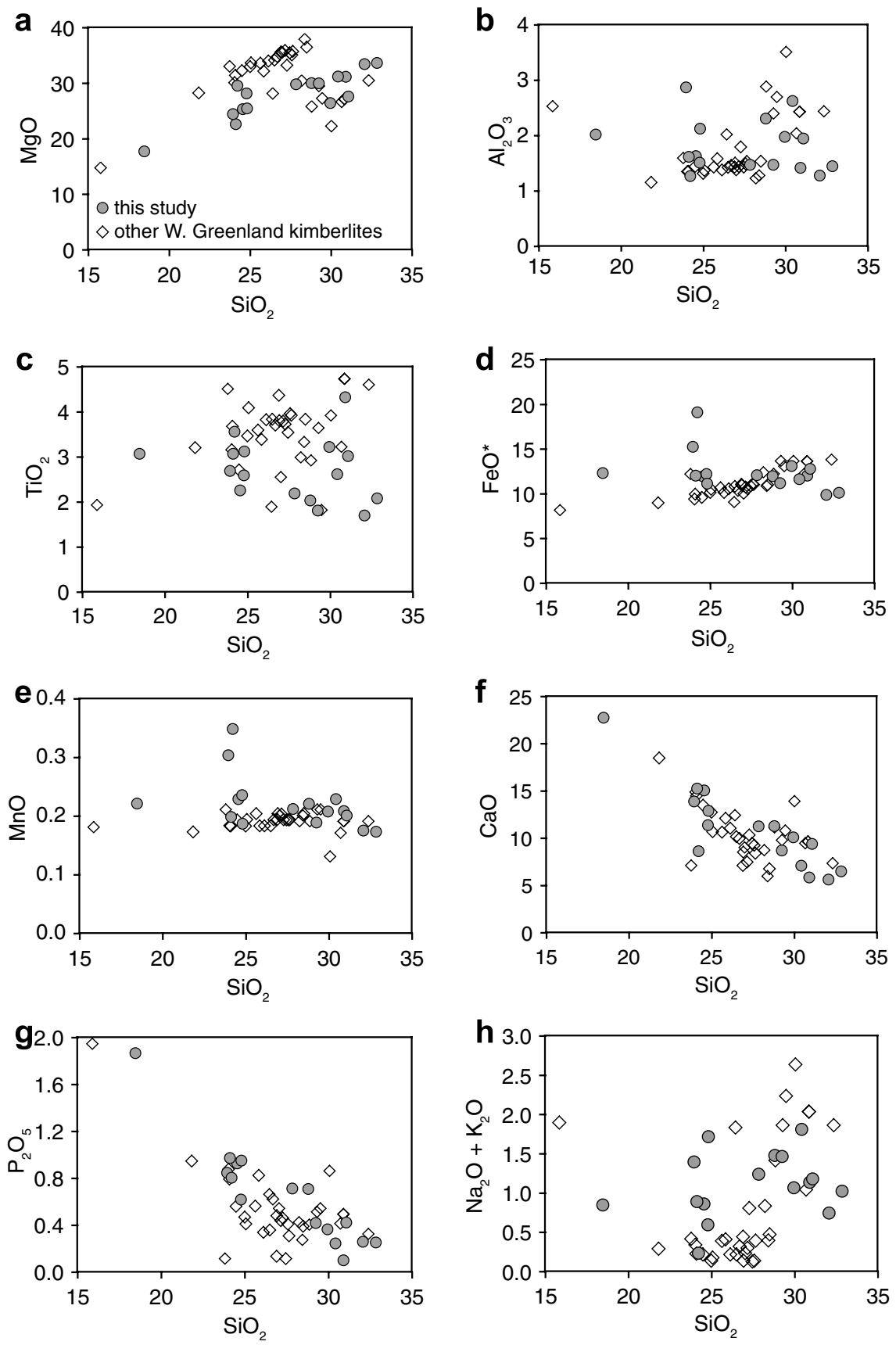

Fig. 2. Major element compositions of West Greenland kimberlites. Oxides given in weight percent. FeO* represents all $\mathrm{Fe}$ as $\mathrm{FeO}$. Compositions plotted are normalized to $100 \%$ (LOI + major and trace element by XRF). The correlations and relative range of data do not change significantly if data are plotted on a volatile-free basis. Also shown for comparison are other kimberlites from the region (diamond symbols, Scott Smith, 1987; Larsen and Rex, 1992; Nielsen and Jensen, 2005).

trace element composition between the samples that erupted on and off the craton.

\subsection{Hf-Nd isotopes}

For analyzed kimberlites, $\varepsilon_{\mathrm{Hfi}}$ ranges from +4.9 to -4.3 , compared to $\varepsilon_{\mathrm{Ndi}}$ values that range from +3.1 to +1.6 (Fig. 5, Table 3). Although no ages were obtained for the particular kimberlite samples that we analyzed, ages have been determined for many kimberlites and associated carbonatites from the Sarfartoq region. Most dated samples fall within the age range of 584-621 Ma $(n=16)$, and two additional samples have older ages, 690 and $706 \mathrm{Ma}$ (Scott, 1981; Larsen et al., 1983; Larsen and Rex, 1992; Bizzarro et al., 2002). We assume here an age of $600 \mathrm{Ma}$ for the kimberlites. The effect of the uncertainty of this age on the cal- 
Table 2

Major and trace element data

\begin{tabular}{|c|c|c|c|c|c|c|c|c|c|c|c|c|c|c|c|c|}
\hline & KIM1 & KIM2 & KIM3 & KIM4 & KIM5 & KIM6 & KIM7 & KIM9 & KIM10 & KIM11 & KIM12 & KIM13 & KIM14 & KIM15 & KIM16 & KIM17 \\
\hline \multicolumn{17}{|l|}{ XRF } \\
\hline LOI (\%) & 10.52 & 12.37 & 16.58 & 17.30 & 18.62 & 11.40 & 14.34 & 12.56 & 11.48 & 11.88 & 13.73 & 15.02 & 16.96 & 11.72 & 13.07 & 20.04 \\
\hline $\mathrm{SiO}_{2}$ & 28.79 & 30.90 & 24.54 & 24.76 & 24.11 & 32.83 & 32.06 & 27.83 & 30.42 & 31.06 & 23.93 & 29.24 & 24.79 & 24.20 & 29.94 & 18.44 \\
\hline $\mathrm{Al}_{2} \mathrm{O}_{3}$ & 2.31 & 1.42 & 1.63 & 1.51 & 1.62 & 1.45 & 1.28 & 1.47 & 2.63 & 1.95 & 2.87 & 1.48 & 2.13 & 1.27 & 1.98 & 2.02 \\
\hline $\mathrm{TiO}_{2}$ & 2.036 & ${ }^{\mathrm{a}} 4.33$ & 2.258 & 2.596 & $\mathrm{a}_{3} 3.07$ & 2.081 & 1.701 & 2.193 & 2.622 & ${ }^{\mathrm{a}} 3.02$ & 2.692 & 1.813 & ${ }^{\mathrm{a}} 3.12$ & $\mathrm{a}_{3} .56$ & $\mathrm{a} 3.22$ & a 3.07 \\
\hline $\mathrm{FeO}^{*}$ & 12.00 & 12.05 & 11.96 & ${ }^{\mathrm{a}} 12.23$ & ${ }^{\mathrm{a}} 12.04$ & 10.12 & 9.89 & 12.10 & 11.64 & 12.81 & ${ }^{\mathrm{a}} 15.26$ & 11.20 & 11.16 & ${ }^{\mathrm{a}} 19.12$ & ${ }^{\mathrm{a}} 13.13$ & ${ }^{\mathrm{a}} 12.33$ \\
\hline $\mathrm{MnO}$ & 0.221 & 0.209 & a 0.23 & a 0.24 & 0.199 & 0.173 & 0.176 & 0.212 & ${ }^{\mathrm{a}} 0.23$ & 0.201 & a 0.30 & 0.189 & 0.187 & ${ }^{\mathrm{a}} 0.35$ & 0.208 & ${ }^{\mathrm{a}} 0.22$ \\
\hline $\mathrm{CaO}$ & 11.30 & 5.86 & ${ }^{\mathrm{a}} 15.08$ & 11.40 & a 15.27 & 6.49 & 5.62 & 11.26 & 7.11 & 9.41 & 13.89 & 8.70 & 12.91 & 8.64 & 10.10 & a 22.77 \\
\hline $\mathrm{MgO}$ & 30.03 & 31.17 & 25.35 & 28.18 & 22.64 & 33.66 & 33.44 & 29.83 & 31.23 & 27.62 & 24.45 & 29.99 & 25.48 & 29.55 & 26.46 & 17.74 \\
\hline $\mathrm{K}_{2} \mathrm{O}$ & 1.434 & 1.063 & 0.834 & 0.571 & 0.894 & 0.948 & 0.673 & 1.183 & 1.763 & 1.040 & 1.343 & 1.126 & 1.672 & 0.199 & 0.984 & 0.850 \\
\hline $\mathrm{Na}_{2} \mathrm{O}$ & 0.047 & 0.075 & 0.027 & 0.028 & n.d. & 0.076 & 0.075 & 0.056 & 0.047 & 0.142 & 0.056 & 0.341 & 0.046 & 0.038 & 0.084 & n.d. \\
\hline $\mathrm{P}_{2} \mathrm{O}_{5}$ & 0.710 & 0.102 & 0.928 & 0.621 & 0.975 & 0.254 & 0.261 & 0.714 & 0.245 & 0.424 & 0.848 & 0.421 & 0.953 & 0.806 & 0.365 & ${ }^{\mathrm{a}} 1.87$ \\
\hline $\mathrm{Ni}$ & 1026 & 1155 & 826 & 927 & 798 & 1423 & 1492 & 1102 & 1135 & 1052 & 402 & 1155 & 807 & 443 & 966 & 325 \\
\hline $\mathrm{Cr}$ & 1434 & 1595 & 1401 & 1685 & 1084 & 1937 & 1865 & 1700 & 1725 & 1379 & 1290 & 1672 & 1247 & 921 & 1560 & 546 \\
\hline $\mathrm{Sc}$ & 20 & 13 & 11 & 12 & 5 & 9 & 8 & 9 & 23 & 12 & 21 & 12 & 12 & 42 & 17 & 9 \\
\hline $\mathrm{V}$ & 149 & 177 & 193 & 196 & 169 & 122 & 100 & 131 & 136 & 188 & 201 & 102 & 145 & 209 & 200 & 176 \\
\hline $\mathrm{Ga}$ & 7 & 8 & 8 & 11 & 6 & 6 & 7 & 8 & 7 & 9 & 14 & 6 & 7 & 9 & 9 & 11 \\
\hline $\mathrm{Cu}$ & 75 & 14 & 75 & 27 & 64 & 64 & 52 & 51 & 105 & 99 & 69 & 55 & 95 & 27 & 99 & 111 \\
\hline $\mathrm{Zn}$ & 70 & 69 & 76 & 79 & 74 & 57 & 56 & 71 & 67 & 71 & 99 & 71 & 69 & 119 & 73 & 74 \\
\hline \multicolumn{17}{|l|}{ ICP-MS } \\
\hline $\mathrm{La}$ & 122.3 & 96.0 & 146.6 & 132.7 & 129.4 & 73.7 & 59.2 & 111.7 & 65.0 & 50.6 & 183.8 & 56.2 & 187.2 & 99.9 & 58.6 & 200.7 \\
\hline $\mathrm{Ce}$ & 237.5 & 177.4 & 265.9 & 275.5 & 251.3 & 138.0 & 109.7 & 222.2 & 128.8 & 104.8 & 371.4 & 115.3 & 365.6 & 183.7 & 123.3 & 352.8 \\
\hline $\mathrm{Pr}$ & 25.8 & 18.9 & 27.7 & 29.5 & 27.6 & 14.5 & 11.5 & 24.3 & 13.9 & 12.2 & 40.4 & 12.8 & 38.7 & 19.9 & 14.3 & 35.6 \\
\hline $\mathrm{Nd}$ & 92.7 & 68.7 & 97.8 & 102.0 & 103.3 & 51.8 & 41.6 & 89.7 & 50.4 & 47.5 & 146.9 & 47.8 & 138.3 & 74.4 & 56.5 & 125.8 \\
\hline $\mathrm{Sm}$ & 13.6 & 10.5 & 14.0 & 12.9 & 16.4 & 7.5 & 6.2 & 13.4 & 7.2 & 8.2 & 20.3 & 6.8 & 21.0 & 11.8 & 9.4 & 18.7 \\
\hline $\mathrm{Eu}$ & 3.52 & 2.82 & 3.59 & 3.03 & 4.39 & 1.93 & 1.63 & 3.50 & 1.82 & 2.27 & 4.93 & 1.72 & 5.40 & 3.12 & 2.60 & 5.09 \\
\hline $\mathrm{Gd}$ & 8.05 & 6.58 & 8.52 & 6.69 & 10.55 & 4.32 & 3.77 & 8.23 & 4.15 & 5.59 & 11.47 & 4.08 & 13.16 & 7.86 & 6.41 & 12.10 \\
\hline $\mathrm{Tb}$ & 0.87 & 0.74 & 0.92 & 0.65 & 1.19 & 0.46 & 0.40 & 0.89 & 0.44 & 0.62 & 1.16 & 0.41 & 1.38 & 0.87 & 0.70 & 1.31 \\
\hline Dy & 3.53 & 3.12 & 3.78 & 2.46 & 5.17 & 1.90 & 1.71 & 3.64 & 1.78 & 2.70 & 4.68 & 1.65 & 5.61 & 3.79 & 3.00 & 5.55 \\
\hline Ho & 0.50 & 0.45 & 0.55 & 0.33 & 0.75 & 0.27 & 0.24 & 0.52 & 0.25 & 0.40 & 0.66 & 0.23 & 0.79 & 0.56 & 0.43 & 0.78 \\
\hline $\mathrm{Er}$ & 0.94 & 0.85 & 1.08 & 0.61 & 1.48 & 0.51 & 0.47 & 1.00 & 0.49 & 0.79 & 1.27 & 0.42 & 1.42 & 1.12 & 0.84 & 1.46 \\
\hline $\mathrm{Tm}$ & 0.10 & 0.08 & 0.12 & 0.07 & 0.15 & 0.06 & 0.05 & 0.11 & 0.06 & 0.08 & 0.13 & 0.04 & 0.15 & 0.12 & 0.09 & 0.15 \\
\hline $\mathrm{Yb}$ & 0.47 & 0.41 & 0.59 & 0.32 & 0.73 & 0.31 & 0.27 & 0.49 & 0.28 & 0.43 & 0.62 & 0.20 & 0.70 & 0.60 & 0.44 & 0.73 \\
\hline $\mathrm{Lu}$ & 0.06 & 0.05 & 0.08 & 0.04 & 0.10 & 0.04 & 0.04 & 0.06 & 0.04 & 0.06 & 0.09 & 0.03 & 0.09 & 0.08 & 0.06 & 0.10 \\
\hline $\mathrm{Ba}$ & 1022 & 541 & 882 & 461 & 742 & 495 & 390 & 751 & 1215 & 316 & 1425 & 333 & 999 & 1432 & 312 & 1052 \\
\hline Th & 11.8 & 9.6 & 12.4 & 15.5 & 12.3 & 10.9 & 9.1 & 10.6 & 7.0 & 4.4 & 28.5 & 5.7 & 21.9 & 13.5 & 5.5 & 21.3 \\
\hline $\mathrm{Nb}$ & 184 & 158 & 185 & 151 & 185 & 102 & 89 & 138 & 168 & 87 & 231 & 81 & 207 & 108 & 94 & 315 \\
\hline $\mathrm{Y}$ & 11.45 & 9.21 & 13.78 & 7.89 & 18.31 & 6.13 & 5.57 & 12.52 & 5.81 & 9.10 & 15.05 & 5.14 & 18.86 & 13.79 & 9.69 & 18.80 \\
\hline Hf & 5.67 & 2.70 & 5.30 & 3.51 & 5.80 & 2.06 & 2.22 & 1.91 & 3.92 & 5.04 & 6.09 & 2.45 & 5.30 & 12.83 & 5.32 & 9.60 \\
\hline \multirow[t]{2}{*}{$\mathrm{Ta}$} & 12.5 & 13.4 & 13.2 & 14.3 & 11.9 & 9.0 & 7.1 & 12.0 & 11.5 & 8.2 & 20.8 & 8.9 & 14.4 & 6.9 & 9.2 & 14.8 \\
\hline & & & & & & & & & & & & & & \multicolumn{3}{|c|}{ (continued on next page) } \\
\hline
\end{tabular}




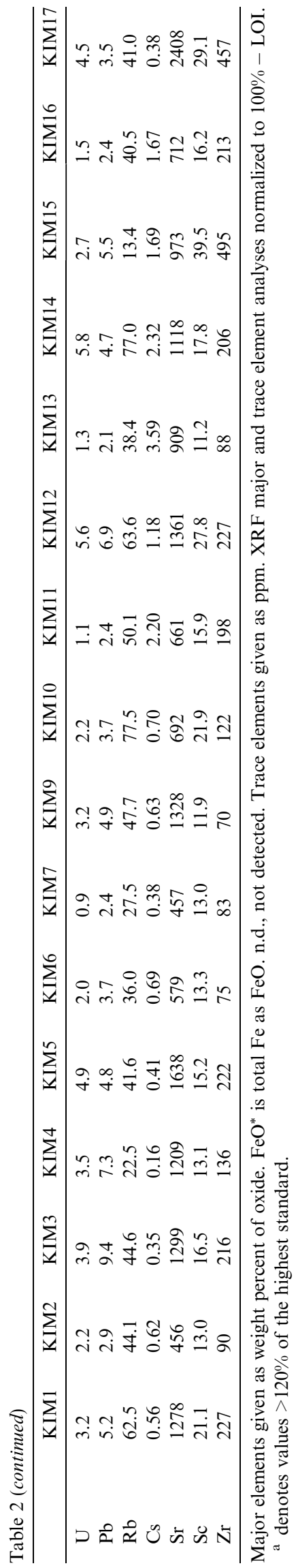

culated initial $\varepsilon_{\mathrm{Hf}}$ and $\varepsilon_{\mathrm{Nd}}$ (assuming an age range of 584 $621 \mathrm{Ma}$ ) is minor; the uncertainty resulting from the age correction is slightly larger than the Hf analytical uncertainty $(<40 \mathrm{ppm}$ compared to $35 \mathrm{ppm}$ external reproducibility), and is smaller than $\mathrm{Nd}$ analytical uncertainty. Using an age of 600 vs. $700 \mathrm{Ma}$ in calculating the initial isotopic compositions of the kimberlites does not result in a significantly different relationship of the kimberlites to the OIB $\varepsilon_{\mathrm{Hf}^{-}-\varepsilon_{\mathrm{Nd}}}$ array discussed below.

Fig. 5 shows $\varepsilon_{\mathrm{Hfi}}$ vs. $\varepsilon_{\text {Ndi }}$ for the West Greenland kimberlite samples. For comparison, we show other published Hf$\mathrm{Nd}$ isotope data for Group I kimberlites: from South Africa (Nowell et al., 2004), West Greenland (Bizzarro et al., 2002), and Canada (Schmidberger et al., 2001, 2002; Bizzarro et al., 2002). These samples have eruption ages that span nearly 1.2 b.y. Vervoort and Blichert-Toft (1999) showed that $\varepsilon_{\mathrm{Hfi}}$ and $\varepsilon_{\mathrm{Ndi}}$ compositions of juvenile rocks of ages ranging from Proterozoic to Mesozoic define an array of similar slope, but offset to slightly lower $\varepsilon_{\mathrm{Hf}}$, as the array of OIBs, defined as: $\varepsilon_{\mathrm{Hf}}=1.33 * \varepsilon_{\mathrm{Nd}}+3.19$ (Vervoort et al., 1999). Thus, because the location of the $\varepsilon_{\mathrm{Hf}}{ }^{-} \varepsilon_{\mathrm{Nd}}$ mantle array has not changed significantly since Archean time, we compare these samples to each other based on their initial $\varepsilon_{\mathrm{Hf}}$ and $\varepsilon_{\mathrm{Nd}}$ compositions. The two previously published analyses of Sarfartoq kimberlite samples (Bizzarro et al., 2002) have $\varepsilon_{\mathrm{Hfi}}-\varepsilon_{\mathrm{Ndi}}$ values within the range of our new data. The South Africa kimberlites also have a similar range in $\varepsilon_{\mathrm{Hfi}}$ values as the West Greenland kimberlites, although a greater proportion of the South Africa samples extend to negative $\varepsilon_{\mathrm{Hfi}}$ values and they also extend to lower $\varepsilon_{\text {Ndi }}$ values than the Greenland samples. In contrast, one Canada kimberlite sample has the highest $\varepsilon_{\mathrm{Ndi}}$, while having $\varepsilon_{\mathrm{Hfi}}$ in the range of the Greenland and South Africa kimberlites, whereas the other two Canada samples fall closer to the range of the West Greenland and South Africa kimberlites. Two additional Canada kimberlite samples have much higher $\varepsilon_{\mathrm{Hfi}}$ values, +17.0 and +21.1 (Schmidberger et al., 2002), than any of the kimberlites discussed here, and are presumed to be contaminated by xenocrystic garnet (Schmidberger et al., 2002). The $\Delta \varepsilon_{\mathrm{Hfi}}$ parameter describes the deviation of a sample from the OIB array in the $y$-axis direction. Most West Greenland samples fall within the range of $\Delta \varepsilon_{\mathrm{Hfi}}=-1.8$ to -4.7 , but one sample (KIM 7) has $\Delta \varepsilon_{\mathrm{Hfi}}=-11.2$ (Fig. 6). Neither the West Greenland nor the South Africa kimberlites show any distinction in $\mathrm{Hf}-\mathrm{Nd}$ isotopic composition relative to the geographic location of sample eruption (Archean craton vs. Proterozoic mobile belt).

\section{DISCUSSION}

A wide variety of sources has been proposed for kimberlite magmas. These include: sub-continental lithospheric mantle (SCLM) (le Roex et al., 2003; Becker and le Roex, 2006), upper mantle (Smith, 1983), lower mantle (Haggerty, 1994), and ancient subducted oceanic crust (Sharp, 1974; Ringwood et al., 1992; Nowell et al., 2004), all of which may be modified by metasomatic processes (e.g., Mitchell, 1986). The presence of diamonds in many kimberlites constrains the depth of kimberlite magma generation to 


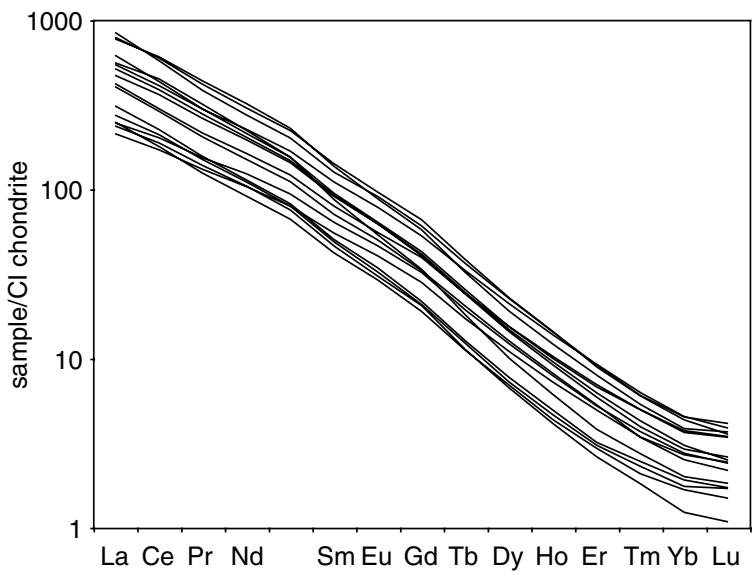

Fig. 3. Rare earth element compositions of West Greenland kimberlites. Element concentrations are normalized to CI chondrite (Sun and McDonough, 1989).
$>150 \mathrm{~km}$ (e.g., Dawson, 1980), and the observation of syngenetic majorite garnet inclusions in diamonds from a South Africa kimberlite (Moore and Gurney, 1985) indicates even greater depths of origin $(\geqslant 400 \mathrm{~km})$ for some kimberlite magmas (Irifune et al., 1989). Based on experimental phase relationships, Ringwood et al. (1992) postulated that kimberlites derive from yet greater depths in the mantle, namely the transition zone $(400-650 \mathrm{~km})$.

The relatively recent observations of apparently ubiquitous negative $\Delta \varepsilon_{\mathrm{Hfi}}$ in kimberlites from regions as geographically distant as West Greenland (this study, Bizzarro et al., 2002), South Africa (Nowell et al., 2004), and Canada (Dowall et al., 2000; Bizzarro et al., 2002; Schmidberger et al., 2002) can be used to rule out several of the postulated kimberlite source regions. The majority of samples of SCLM, in the form of eclogite and peridotite xenoliths, have positive $\Delta \varepsilon_{\mathrm{Hfi}}$, and thus SCLM is not a reasonable kimberlite source (Schmidberger et al., 2002; Nowell
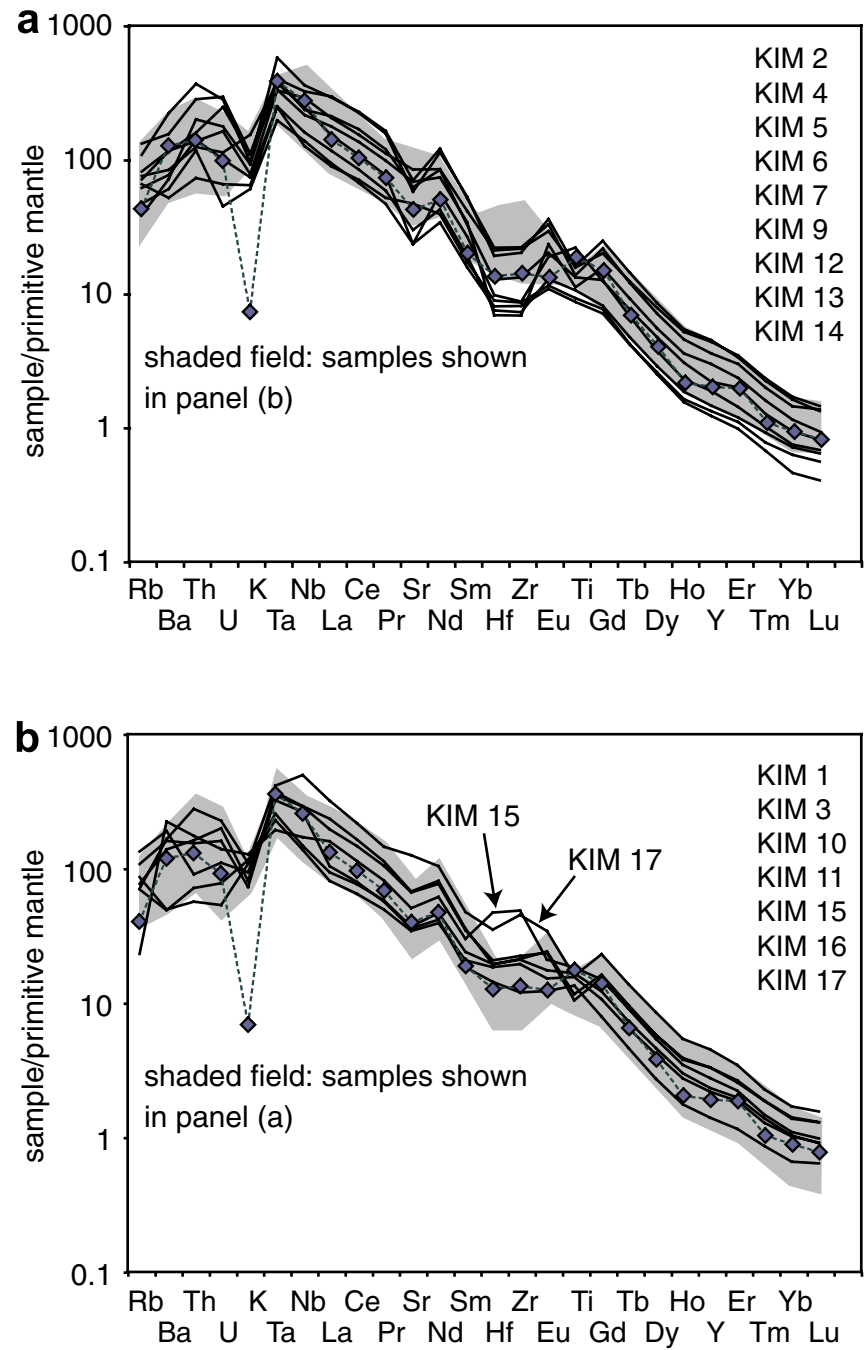

Fig. 4. Incompatible element 'spider diagrams'. Element concentrations are normalized to Primitive Mantle (Sun and McDonough, 1989). Data are shown in two panels to more clearly illustrate the variation represented by the set of samples as a whole. (a) shows samples with Hf$\mathrm{Zr}$ depletion. (b) shows samples lacking pronounced $\mathrm{Hf}-\mathrm{Zr}$ depletion. For comparison, the average composition of other kimberlites from the region is also plotted (dashed line with diamond symbols, Nielsen and Jensen, 2005). 

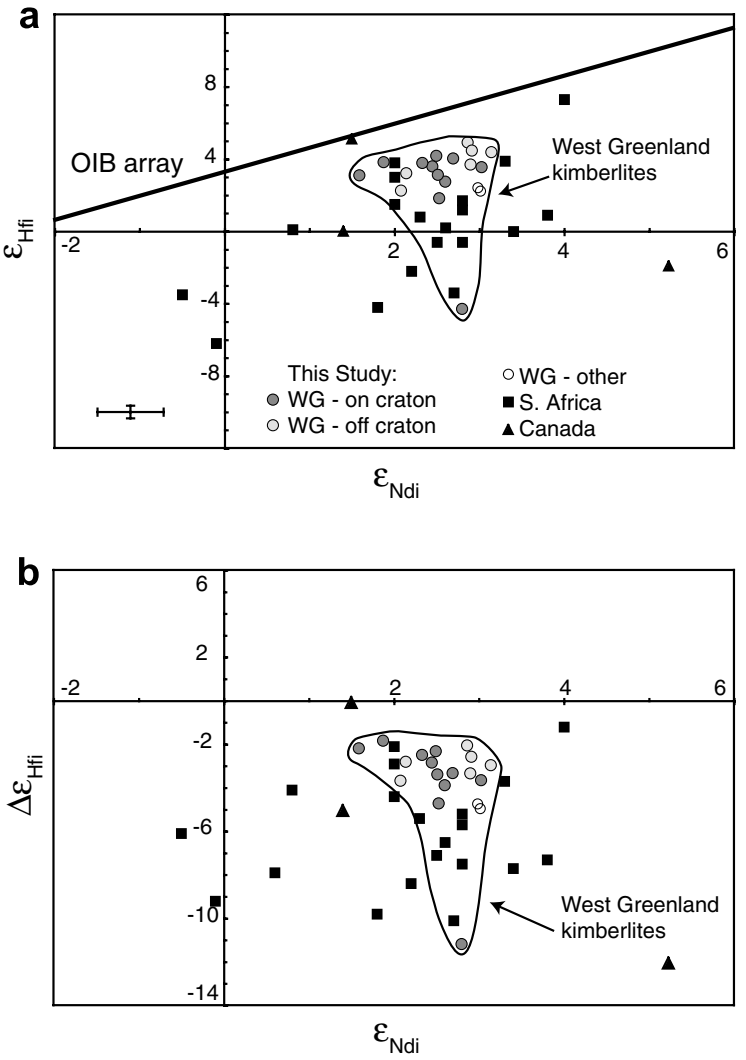

Fig. 5. (a) $\varepsilon_{\mathrm{Hf}}-_{\mathrm{Ndi}}$ compositions of West Greenland kimberlites. Initial isotopic compositions calculated at $0.6 \mathrm{Ga}$. OIB array: $\varepsilon_{\mathrm{Hf}}=1.33 * \varepsilon_{\mathrm{Nd}}+3.19$ (Vervoort et al., 1999). Error bar shows $2 \sigma$ analytical uncertainty. Also shown are South Africa Group I kimberlites (Nowell et al., 2004), Canada kimberlites (Schmidberger et al., 2001, 2002; Bizzarro et al., 2002), and previously published West Greenland kimberlites (Bizzarro et al., 2002). Data reported by Schmidberger et al. (2002) and interpreted to be contaminated by crustal material are not plotted. (b) $\varepsilon_{\mathrm{Ndi}}-\Delta \varepsilon_{\mathrm{Hfi}}$ variation in kimberlites. $\Delta \varepsilon_{\mathrm{Hfi}}$ notation defines deviation in the $\mathrm{y}$ axis direction of a given sample from the OIB reference line.

et al., 2004; Ionov et al., 2005). The high (up to $25 \mathrm{R}_{\mathrm{A}}$; Tachibana et al., 2006) ${ }^{3} \mathrm{He} /{ }^{4} \mathrm{He}$ compositions of the Greenland kimberlites also rule out SCLM, which is characterized by low ${ }^{3} \mathrm{He} /{ }^{4} \mathrm{He}$ (Dunai and Porcelli, 2002; Day et al., 2005), as a kimberlite source. Primitive sources in the upper and lower mantle further can be excluded based on their $\mathrm{Hf}-\mathrm{Nd}$ isotope compositions. Although OIB-source mantle is consistent with $\mathrm{Sr}-\mathrm{Nd}-\mathrm{Pb}$ isotope compositions, no known OIBs have negative $\Delta \varepsilon_{\mathrm{Hfi}}$ values of a magnitude similar to those observed in some kimberlite samples. Although HIMU-type OIBs are characterized by negative $\Delta \varepsilon_{\text {Hfi }}$ values, they still fall within the lower extremity of the broad $\varepsilon_{\mathrm{Hf}}-\varepsilon_{\mathrm{Nd}}$ array defined by a global sampling of OIBs (e.g., Lassiter et al., 2003; Nelson and Blichert-Toft, 2004). The carbonate fractions of some carbonatites from East Africa have strongly negative $\Delta \varepsilon_{\mathrm{Hfi}}$ values, but this has been shown to reflect a relatively short-lived source component related to initial melting in an ascending plume, rather than characterize a wide-spread, long-lived mantle component (Bizimis et al., 2003). The remaining two plausible mantle sources that are consistent with negative $\Delta \varepsilon_{\mathrm{Hfi}}$ are: (a) ancient, subducted oceanic crust or (b) ancient perovskitebearing material separated during the crystallization of a magma ocean (Kato et al., 1988, 1996).

\subsection{Perovskite-bearing kimberlite mantle source}

An ancient Mg-perovskite-bearing mantle source would have negative $\Delta \varepsilon_{\mathrm{Hf}}$ as required for the kimberlite source region. Such a source may have formed as a perovskite-bearing residue from ancient deep-mantle melting (Blichert-Toft and Albarède, 1997). Alternatively, it could be a perovskiterich cumulate from an early magma ocean (Kato et al., 1988, 1996; Salters and White, 1998; Corgne et al., 2005). Mg-perovskite has $D_{\mathrm{Sm}}>D_{\mathrm{Nd}}$ and $D_{\mathrm{Lu}}<D_{\mathrm{Hf}}$ (Corgne et al., 2005), such that a $\mathrm{Mg}$-perovskite-rich reservoir will evolve to negative $\Delta \varepsilon_{\mathrm{Hfi}}$ values. In contrast, Ca-perovskite has $D_{\mathrm{Sm}}>D_{\mathrm{Nd}}$ and $D_{\mathrm{Lu}}>D_{\mathrm{Hf}}$. Although a perovskite-rich layer may have formed in early Earth history, there is little evidence to suggest that a large perovskite-rich layer survived past the first few 100s of m.y. of its existence (Kato et al., 1988; Corgne et al., 2005). Based on chondritic proportions of refractory lithophile elements in mantle-derived rocks, any perovskite fractionation from an early magma ocean must have been either minimal in extent or effectively re-homogenized with the remainder of the mantle (Corgne et al., 2005). Furthermore, observations of chondritic ${ }^{176} \mathrm{Hf} /{ }^{177} \mathrm{Hf}$ in $>4.0 \mathrm{Ga}$ zircons likewise indicate that any perovskite fractionation that accompanied crystallization of an early magma ocean must have been re-homogenized within a few 100s of million years, that is, prior to formation of the zircons (Kato et al., 1988; Kinny et al., 1991; Amelin et al., 1999). The recent expansion of the database of ${ }^{176} \mathrm{Hf} /{ }^{177} \mathrm{Hf}$ measurements in $>4.0 \mathrm{Ga}$ zircons show a range in $\varepsilon_{\mathrm{Hf}}$ extending from positive to negative values that is consistent with early formation of crust and mantle domains (Harrison et al., 2005). Thus, although a perovskite-rich layer in the mantle may have formed early in Earth's history, there is little evidence to uniquely indicate that it has been or is a persistent feature of the mantle, and therefore not a viable possibility as a source for the kimberlites.

\subsection{Ancient oceanic crust in the kimberlite source}

Ancient subducted oceanic crust is predicted to have negative $\Delta \varepsilon_{\mathrm{Hf}}$ values and, based on this characteristic, has been proposed as a source component for kimberlites (Nowell et al., 2004) as well as HIMU-type OIB (Salters and White, 1998). However, important isotopic and major and trace element differences between HIMU-type OIBs and kimberlites indicate that kimberlites and OIBs result from fundamentally different processes of magma genesis. Kimberlites show greater negative deviation from the $\varepsilon_{\mathrm{Hf}^{-}}$ $\varepsilon_{\mathrm{Nd}}$ OIB reference line than HIMU basalts which, though characterized by negative $\Delta \varepsilon_{\mathrm{Hf}}$, generally fall within the $\varepsilon_{\mathrm{Hf}}{ }^{-} \varepsilon_{\mathrm{Nd}}$ field defined by a global sampling of OIBs. Furthermore, kimberlite magmas have much higher volatile contents, dominantly $\mathrm{CO}_{2}$ as reflected by the typical presence of primary carbonate, and they are far more alkaline in nat- 
Table 3

$\mathrm{Lu}-\mathrm{Hf}$ and $\mathrm{Sm}-\mathrm{Nd}$ isotope data

\begin{tabular}{|c|c|c|c|c|c|c|c|c|c|c|c|c|}
\hline Sample & {$[\mathrm{Lu}]^{\mathrm{a}}$} & {$[\mathrm{Hf}]^{\mathrm{a}}$} & ${ }^{176} \mathrm{Lu} /{ }^{177} \mathrm{Hf}^{\mathrm{a}}$ & ${ }^{176} \mathrm{Hf} /{ }^{177} \mathrm{Hf}^{b}$ & \pm & $\varepsilon_{\mathrm{Hf}}(0.6)^{\mathrm{d}}$ & {$[\mathrm{Sm}]^{\mathrm{a}}$} & {$[\mathrm{Nd}]^{\mathrm{a}}$} & ${ }^{147} \mathrm{Sm} /{ }^{144} \mathrm{Nd}^{\mathrm{a}}$ & ${ }^{143} \mathrm{Nd} /{ }^{144} \mathrm{Nd}^{\mathrm{c}}$ & \pm & $\varepsilon_{\mathrm{Nd}}(0.6)^{\mathrm{d}}$ \\
\hline Kim 1 & 0.06 & 5.33 & 0.00155 & 0.282494 & 8 & 2.8 & 12.292 & 94.68 & 0.0785 & 0.512306 & 7 & 2.6 \\
\hline Kim 2 & 0.05 & 2.92 & 0.00241 & 0.282544 & 8 & 4.2 & 10.052 & 74.06 & 0.0821 & 0.512315 & 7 & 2.5 \\
\hline Kim 3 & 0.08 & 5.79 & 0.00200 & 0.282473 & 7 & 1.8 & 14.328 & 114.29 & 0.0758 & 0.512292 & 4 & 2.5 \\
\hline Kim 4 & 0.05 & 3.87 & 0.00174 & 0.282506 & 6 & 3.1 & 12.302 & 110.45 & 0.0674 & 0.512211 & 6 & 1.6 \\
\hline Kim 5 & 0.09 & 4.78 & 0.00262 & 0.282530 & 6 & 3.6 & 17.240 & 124.40 & 0.0838 & 0.512319 & 6 & 2.4 \\
\hline Kim 6 & 0.04 & 2.00 & 0.00272 & 0.282518 & 6 & 3.2 & 6.475 & 51.12 & 0.0766 & 0.512294 & 5 & 2.5 \\
\hline Kim 7 & 0.04 & 2.38 & 0.00214 & 0.282302 & 7 & -4.3 & 6.088 & 45.27 & 0.0813 & 0.512327 & 5 & 2.8 \\
\hline Kim 9 & 0.06 & 1.66 & 0.00492 & 0.282563 & 12 & 3.9 & 11.483 & 85.71 & 0.0810 & 0.512321 & 5 & 2.7 \\
\hline $\operatorname{Kim} 9 r^{e}$ & 0.06 & 2.12 & 0.00408 & 0.282564 & 11 & 4.2 & & & & & & \\
\hline Kim 10 & 0.04 & 4.64 & 0.00132 & 0.282522 & 13 & 3.9 & 7.200 & 57.63 & 0.0756 & 0.512257 & 6 & 1.9 \\
\hline Kim 11 & 0.06 & 5.48 & 0.00152 & 0.282540 & 7 & 4.4 & 8.030 & 53.46 & 0.0908 & 0.512382 & 6 & 3.1 \\
\hline Kim 12 & 0.09 & 6.16 & 0.00197 & 0.282485 & 7 & 2.3 & 18.295 & 150.11 & 0.0737 & 0.512261 & 6 & 2.1 \\
\hline Kim 13 & 0.03 & 2.38 & 0.00152 & 0.282507 & 10 & 3.2 & 6.595 & 52.10 & 0.0766 & 0.512275 & 5 & 2.1 \\
\hline Kim 14 & 0.09 & 5.45 & 0.00229 & 0.282529 & 8 & 3.7 & 20.827 & 157.27 & 0.0801 & 0.512328 & 5 & 2.9 \\
\hline Kim 15 & 0.09 & 16.57 & 0.00079 & 0.282547 & 6 & 4.9 & 12.352 & 89.80 & 0.0832 & 0.512338 & 6 & 2.9 \\
\hline Kim 16 & 0.06 & 5.74 & 0.00148 & 0.282542 & 6 & 4.5 & 9.199 & 61.67 & 0.0902 & 0.512368 & 6 & 2.9 \\
\hline Kim 17 & 0.09 & 9.54 & 0.00139 & 0.282515 & 7 & 3.6 & 21.283 & 166.60 & 0.0773 & 0.512323 & 8 & 3.0 \\
\hline Kim 18 & 0.12 & 5.72 & 0.00285 & 0.282538 & 7 & 3.8 & 12.174 & 90.84 & 0.0811 & 0.512302 & 6 & 2.3 \\
\hline
\end{tabular}

${ }^{a}$ Elemental concentrations are given in ppm. Uncertainties for $\mathrm{Lu}, \mathrm{Hf}, \mathrm{Sm}$ and $\mathrm{Nd}$ concentrations, ${ }^{176} \mathrm{Lu} /{ }^{177} \mathrm{Hf}$ and ${ }^{147} \mathrm{Sm} /{ }^{144} \mathrm{Nd}$ are $<0.5 \%$.

${ }^{176} \mathrm{Hf} /{ }^{177} \mathrm{Hf}$ corrected for mass fractionation to ${ }^{179} \mathrm{Hf} /{ }^{177} \mathrm{Hf}=0.7325$. JMC-475 Hf standard gave ${ }^{176} \mathrm{Hf} /{ }^{177} \mathrm{Hf}=0.28216 \pm 0.00001$. Analytical uncertainties reported are in the last decimal place, and are $2 \sigma / \sqrt{n}$, where $n$ is the number of measured isotope ratios.

${ }^{c}{ }^{143} \mathrm{Nd} /{ }^{144} \mathrm{Nd}$ corrected for mass fractionation to ${ }^{146} \mathrm{Nd} /{ }^{144} \mathrm{Nd}=0.7219$. See text for details of ${ }^{143} \mathrm{Nd} /{ }^{144} \mathrm{Nd}$ normalization procedure. Analytical uncertainties reported are in the last decimal place, and are $2 \sigma / \sqrt{n}$, where $n$ is the number of measured isotope ratios.

${ }^{\mathrm{d}} \varepsilon_{\mathrm{Hf}}$ and $\varepsilon_{\mathrm{Nd}}$ values calculated at $0.6 \mathrm{Ga}$, using ${ }^{176} \mathrm{Hf} /{ }^{177} \mathrm{Hf}_{\mathrm{CHUR}(0)}=0.282772, \quad{ }^{176} \mathrm{Lu} /{ }^{177} \mathrm{Hf}_{\mathrm{CHUR}(0)}=0.0332, \quad{ }^{143} \mathrm{Nd} /{ }^{144} \mathrm{Nd} \mathrm{CHUR}_{\mathrm{CH}(0)}=0.512638, \quad{ }^{147} \mathrm{Sm} /{ }^{144} \mathrm{Nd} \mathrm{CHUR}_{\mathrm{CH}(0)}=0.1967, \quad \lambda$

${ }^{176} \mathrm{Lu}=1.865 \times 10^{-11} \mathrm{y}^{-1}$ and $\lambda^{147} \mathrm{Sm}=6.54 \times 10^{-12} \mathrm{y}^{-1}$

${ }^{\mathrm{e}}$ Duplicate dissolution and analysis. 


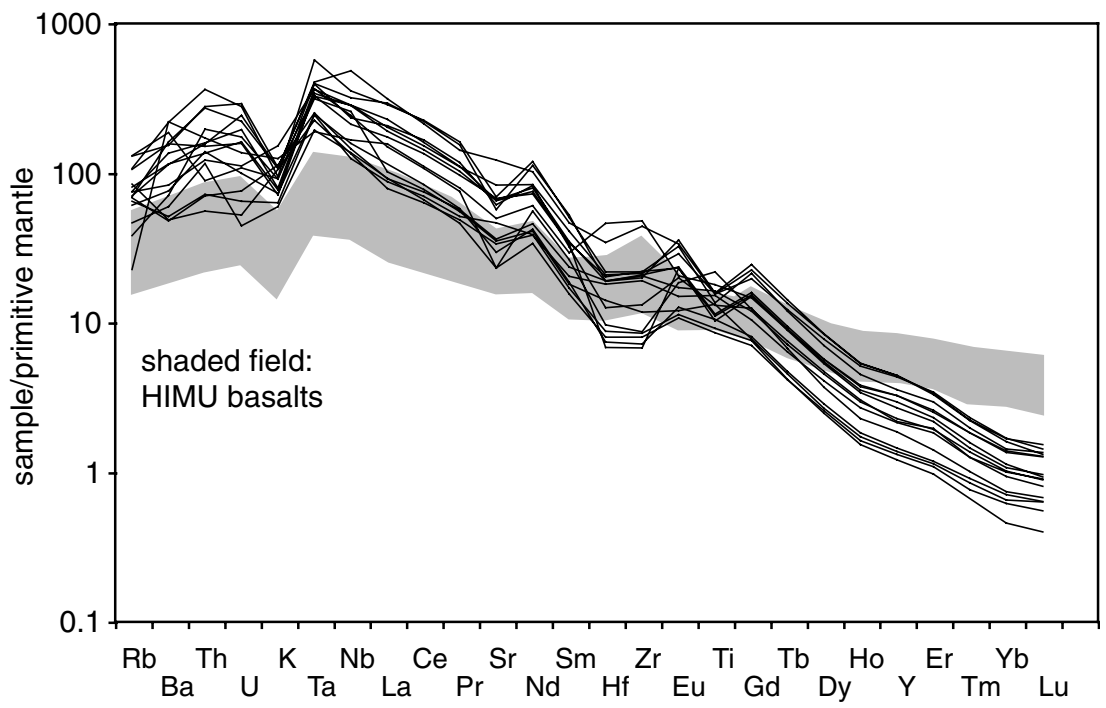

Fig. 6. Comparison of West Greenland kimberlite incompatible trace element compositions to HIMU-type OIBs. HIMU data from Willbold and Stracke (2006). Compositions normalized to primitive mantle (Sun and McDonough, 1989).

ure. Additionally, kimberlites have $\mathrm{Hf}-\mathrm{Zr}$ depletions and $\mathrm{Ta}-\mathrm{Nb}$ enrichments in primitive-mantle normalized spider diagrams. In comparison, HIMU-type OIBs are characterized by $\mathrm{Zr}$ (and sometimes Hf) enrichments, along with flat Ta-Nb patterns (Fig. 6). Kimberlites also show a much stronger depletion in HREE than HIMU-type OIBs. Lastly, HIMU lavas are characterized by ${ }^{3} \mathrm{He} /{ }^{4} \mathrm{He}$ similar to or lower than MORB values, consistent with the interpretation of their source as ancient oceanic crust $(\sim 5-$ $7 \mathrm{R}_{\mathrm{A}}$; Moreira and Kurz, 2001), whereas the Greenland kimberlites have ${ }^{3} \mathrm{He} /{ }^{4} \mathrm{He}$ that range from lower than MORB-like values $\left(6 \mathrm{R}_{\mathrm{A}}\right)$ to very 'primitive' values (25 $\mathrm{R}_{\mathrm{A}}$ ) (Tachibana et al., 2006).

Dewatering as well as melting of oceanic crust during subduction should generate distinctive trace element fractionations. Phase transitions resulting from dewatering and melting reactions in the downgoing slab are complex and depend upon the composition and alteration history of the oceanic crust as well as the thermal regime of the subduction zone. However, a few generalizations can be made. Dewatering accompanies the transition of hydrothermally altered basalt/amphibolite to eclogite, and takes place over a large pressure range, up to $\sim 6 \mathrm{GPa}$ in some subduction zones (Poli and Schmidt, 1995; Schmidt and Poli, 1998). Slab melting may begin at $P>1.5 \mathrm{GPa}$, within the stability range of both garnet and rutile in the slab (carbonated: Yaxley and Green, 1994; carbonate-free: Xiong et al., 2005). In hotter mantle regimes characteristic of earlier Earth history, slab melting may have been much more prevalent than today (Defant and Drummond, 1990; Leybourne et al., 1999).

The presence of residual rutile generates distinctive high field strength element (HFSE) patterns during both dewatering and melting of oceanic crust in the subduction zone, which would be expected to be evident in the trace element patterns of the kimberlites. Experiments on trace-element partitioning between fluid and residual clinopyrox- ene + garnet \pm rutile assemblages show that the presence or absence of rutile has a significant effect on the partitioning behavior of HFSEs (Stalder et al., 1998). During rutileabsent dewatering, HFSEs have $D^{\text {fluid-solid }}$ greater than one to slightly less than one. With rutile present in the residue, HFSEs are generally retained in the residual assemblage, and thus the dewatering residue should have a positive $\mathrm{Hf}-\mathrm{Zr}$ anomaly, opposite to what is observed in the kimberlites. Distinctive partitioning of HFSEs are also observed in melting experiments of rutile-bearing amphibolite and eclogite. These show that melting residues have $\mathrm{Nb}$ enrichment but slight $\mathrm{Zr}-\mathrm{Hf}$ depletion (Foley et al., 2000; Barth et al., 2002a). These results are consistent with observations of eclogite xenoliths inferred to be the residues of subduction zone processing of oceanic crust (Barth et al., 2001; Barth et al., 2002b) and are also similar to characteristics observed in the West Greenland kimberlites. The similarity of these trace element patterns, as well as their uniqueness, present additional support for the presence of recycled oceanic crust, from which a small amount of melt has been extracted, in the kimberlite mantle source.

Lutetium-Hf fractionation also results from dewatering or melting of a garnet + rutile bearing assemblage, such as is stable in subducted oceanic crust at $P>1.5 \mathrm{GPa}$. However, in the model presented in Fig. 7, we show that the effects of dewatering and melting on the $\varepsilon_{\mathrm{Hf}^{-}-\varepsilon_{\mathrm{Nd}}}$ evolution of subducted oceanic crust are minor. For the phase proportions gt:cpx:rt 0.475:0.475:0.05, and using partition coefficients from Barth et al. (2001), Foley et al. (2000), and Stalder et al. (1998) (tabulated in the caption of Fig. 7), $D_{\mathrm{Lu}}$ and $D_{\mathrm{Hf}}$ are $>1$ for both dewatering and melting. Also, for both dewatering and melting, $D_{\mathrm{Lu}} / D_{\mathrm{Hf}}$ and $D_{\mathrm{Sm}} / D_{\mathrm{Nd}}$ are $>1$, so $\mathrm{Lu} / \mathrm{Hf}$ and $\mathrm{Sm} / \mathrm{Nd}$ of the residues of melting or dewatering are slightly greater than the starting compositions of MORB. In this calculation, the small amounts of melt or fluid generated from the downgoing slab are assumed to be efficiently extracted and separated from the 


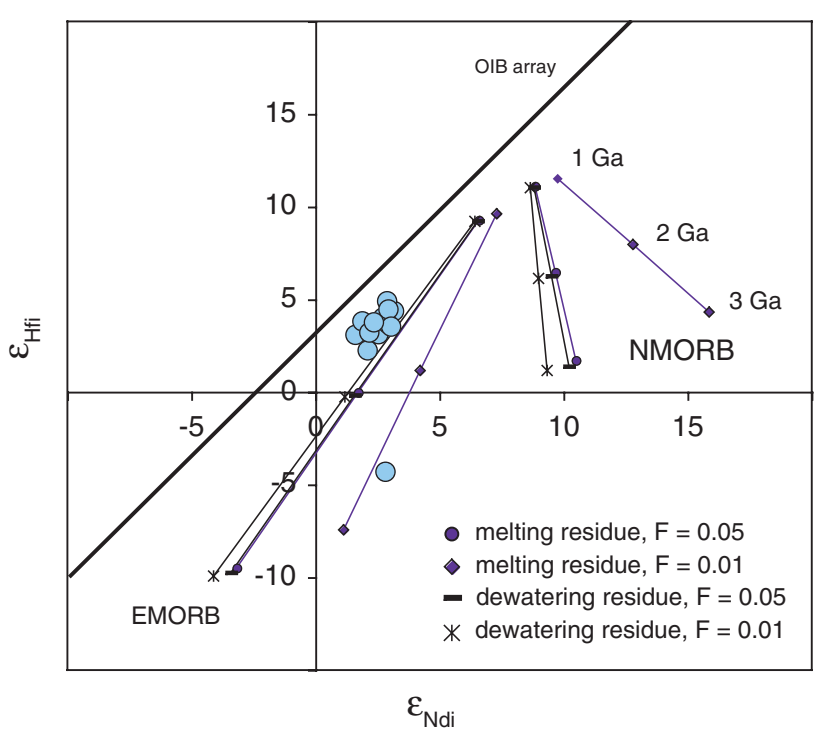

Fig. 7. $\varepsilon_{\mathrm{Hf}}-\varepsilon_{\mathrm{Nd}}$ evolution of subducted oceanic crust. Circle symbols are West Greenland kimberlites. Curves represent isotopic composition at $0.6 \mathrm{Ga}$ of oceanic crust formed and subducted at 1,2, and $3 \mathrm{Ga}$. Right-hand set of curves represents evolution of NMORB, and left-hand set of curves represents evolution of EMORB (Sun and McDonough, 1989). Individual curves are for evolution of solid residues of $1 \%$ and 5\% subduction zone dewatering, and $1 \%$ and $5 \%$ subduction zone melting (batch melting). For clarity, evolution curves for unmelted and undewatered NMORB and EMORB are not plotted, but they closely coincide with the curves for the melting and dewatering residues for $F=0.05$. Partition coefficients used in the melting calculations are, for $\mathrm{Sm}, \mathrm{Nd}, \mathrm{Lu}$ and $\mathrm{Hf}$, respectively: $0.582,0.2,9,0.47$ for garnet; 0.84 , 0.396, 1.3, 0.53 for clinopyroxene; and 0.0164, 0.0085, 0.0142, 4.97 for rutile. Partition coefficients used in dewatering calculations are, for Sm, $\mathrm{Nd}$, Hf and Lu, respectively: 0.64, 0.51, 34.48, 3.45 for garnet; $0.91,0.73,0.91,8.33$ for bulk clinopyroxene and rutile, in 9:1 proportions. Partition coefficients are from Barth et al. (2001), Foley et al. (2000), and Stalder et al. (1998); values for Nd and Lu in dewatering calculation are interpolated from values for neighboring REE.

residual slab. We determined the ${ }^{143} \mathrm{Nd} /{ }^{144} \mathrm{Nd}$ and ${ }^{176} \mathrm{Hf} /{ }^{177} \mathrm{Hf}$ composition of MORB at 3, 2, and $1 \mathrm{Ga}$, assuming that the depleted MORB source formed from chondritic mantle at $4 \mathrm{Ga}$. The modern composition of this depleted mantle reservoir is ${ }^{143} \mathrm{Nd} /{ }^{144} \mathrm{Nd}=0.513150$, ${ }^{176} \mathrm{Hf} /{ }^{177} \mathrm{Hf}=0.283200, \quad{ }^{147} \mathrm{Sm} /{ }^{144} \mathrm{Nd}=0.216, \quad$ and ${ }^{176} \mathrm{Lu} /{ }^{177} \mathrm{Hf}=0.0387$. The calculated effects on the $\varepsilon_{\mathrm{Hf}}$ $\varepsilon_{\mathrm{Nd}}$ composition of the residual oceanic crust at $0.6 \mathrm{Ga}\left(t_{\mathrm{i}}\right.$ of the kimberlites) assume $\mathrm{Lu} / \mathrm{Hf}$ and $\mathrm{Sm} / \mathrm{Nd}$ of $\mathrm{NMORB}$ and EMORB (Sun and McDonough, 1989) and 1\% and 5\% dewatering and $1 \%$ and $5 \%$ melting (Fig. 7). This recycled crust component does not include sedimentary material, which is not predicted to have the appropriate $\mathrm{Hf}-\mathrm{Nd}$ isotopic characteristics to be a source component of the kimberlites (e.g., Blichert-Toft et al., 1999).

The first-order observation is that neither dewatering nor melting significantly alters the direction of the $\varepsilon_{\mathrm{Hf}}-\varepsilon_{\mathrm{Nd}}$ evolutionary trajectory of MORB, compared to the unmelted/un-dewatered composition. Both ancient NMORB and EMORB have negative $\Delta \varepsilon_{\mathrm{Hfi}} ;$ however, ancient NMORB has $\varepsilon_{\text {Ndi }}$ higher than observed in kimberlites. While different degrees of melting ( $1 \%$ vs. $5 \%)$ create slight differences in the evolutionary trajectories of the residues, different degrees of dewatering have no effect. Although it is expected that neither dewatering nor melting will cause significant fractionation of $\mathrm{Sm} / \mathrm{Nd}, \mathrm{Lu}$ and $\mathrm{Hf}$ are each compatible in one of the phases involved. Because $\mathrm{Lu}$ is compatible in residual garnet, and $\mathrm{Hf}$ is compatible in residual rutile, there is less fractionation of $\mathrm{Lu} / \mathrm{Hf}$ during dewatering or melting than would be expected if rutile were absent. These calculations indicate that the kimberlite $\varepsilon_{\mathrm{Hf}}-\varepsilon_{\mathrm{Nd}}$ compositions are consistent with ancient subducted oceanic crust in their mantle source.

Recent studies of terrestrial magmas by Boyet and Carlson $(2005,2006)$ have resolved small $(0.2 \varepsilon$ unit), near-constant, positive deviations from the chondritic $\varepsilon_{142 \mathrm{Nd}}$ value, and present a discussion of the geologic meaning of a chondritic reference point for mantle-derived magmas. Assuming that bulk silicate Earth has chondritic abundances of refractory, lithophile elements, Boyet and Carlson (2005, 2006) conclude that the supra-chondritic $\varepsilon_{142 \mathrm{Nd}}$ values in mantle-derived magmas reflect early, global differentiation of Earth into an enriched reservoir, which has never been sampled and remains hidden in the mantle, and a depleted reservoir, which is the source for all magmas erupted at Earth's surface. Several of the kimberlite samples from our study were also analyzed by Boyet and Carlson (2006) and all were found to have supra-chondritic $\varepsilon_{142 \mathrm{Nd}}$ values. It is conceivable that these kimberlites tap a primitive remnant of the 'early depleted reservoir', which had escaped differentiation into depleted mantle and crust components as they are known today. Although the Sm/ $\mathrm{Nd}$ ratio of the early depleted reservoir is quantifiable, the ways in which global differentiation may have affected the $\mathrm{Lu} / \mathrm{Hf}$ ratio of the early depleted reservoir remain unclear. Boyet and Carlson (2006) estimated the composition of the early depleted reservoir at $3 \mathrm{Ga} \quad\left(\varepsilon_{\mathrm{Hf}}=+4\right.$ and $\left.\varepsilon_{\mathrm{Nd}}=+2.7\right)$ and at present $\left(\varepsilon_{\mathrm{Hf}}=+12.2\right.$ and $\left.\varepsilon_{\mathrm{Nd}}=+4.9\right)$. The estimated modern composition has a positive $\Delta \varepsilon_{\mathrm{Hfi}}$ value, and therefore is not a suitable source for the kimber- 
lites. Furthermore, the trace element characteristics of the kimberlites are not consistent with a source in the "primitive' depleted mantle. However, using the Boyet and Carlson (2006) $3 \mathrm{Ga}$ mantle composition as the starting point for depleted mantle evolution in our model for aged oceanic crust generates oceanic crust evolutionary trajectories that are nearly identical to those presented in Fig. 7. Thus, the conclusions drawn from our model are independent of whether the oceanic crust was extracted from depleted mantle that originated from chondritic mantle at $4 \mathrm{Ga}$ or the 'early depleted reservoir' at $3 \mathrm{Ga}$.

\subsection{A model for kimberlite formation}

The trace element and isotopic observations and calculations presented in the previous section provide a framework to infer processes of subduction, storage, metasomatism, and source melting involved in kimberlite magma generation. During subduction, hydrothermally altered basaltic oceanic crust dehydrates and also melts to a small degree. This small-degree melt is lost from the system in the subduction zone. Rutile remains as a residual phase during this process, thus imparting the 'rutile signature' on the partially melted crust. Carbonate in the oceanic crust, formed during hydrothermal alteration of the crust at the mid-ocean ridge, remains stable through subduction and thus accompanies the oceanic crust into the mantle (Yaxley and Green, 1994; Hammouda, 2003; Dasgupta et al., 2004). As the crust subducts to greater depths in the mantle, rutile breaks down as $\mathrm{Ti}$ is partitioned into garnet (Ringwood, 1990). Subducted oceanic crust is stored in the mantle for times on the order of 1-3 b.y., possibly remaining physically associated with the Archean craton beneath which it subducted. Melting begins with a first stage of very small-degree melt of the now rutile-free ancient subducted oceanic crust. This carbonate- and incompatible element-rich melt, carrying the HFSE signature of rutile, percolates into and 'fertilizes' proximal peridotitic mantle. The metasomatized peridotitic mantle subsequently melts to give rise to carbonate-rich kimberlites, which have the isotopic and trace element signatures of the ancient subducted oceanic crust.

The models presented here show that a kimberlite source component of ancient oceanic crust that has undergone subduction zone dewatering and possibly small amounts of partial melting is consistent with the $\varepsilon_{\mathrm{Hf}}-\varepsilon_{\mathrm{Nd}}$ systematics that we observe. According to our calculations, an EMORB-type starting composition for the oceanic crust, combined with storage times on the order of 1-3 b.y., are required to produce the $\varepsilon_{\mathrm{Nd}}-\varepsilon_{\mathrm{Hf}}$ compositions of the kimberlites. Although NMORB-type compositions also result in negative $\Delta \varepsilon_{\mathrm{Hfi}}$ values, the $\varepsilon_{\mathrm{Ndi}}$ compositions are too high. Mixing of ancient NMORB with local peridotitic mantle, which probably is similar in composition to that sampled by ocean island basalts, and thus ranges from moderately depleted to 'primitive' in its isotopic composition (e.g., Smith, 1983; le Roex, 1986), may result in $\varepsilon_{\mathrm{Nd}}-\varepsilon_{\mathrm{Hf}}$ compositions similar to those of the kimberlites. However, as recycled oceanic crust dominates the trace element signatures of the kimberlites, this scenario is unlikely. Regardless, the combination of starting composition of the oceanic crust and the storage time exerts a much greater control on the $\varepsilon_{\mathrm{Hf}}{ }^{-} \varepsilon_{\mathrm{Nd}}$ evolution than the dewatering or partial melting that oceanic crust experiences as it subducts.

We favor a model with long storage times of subducted oceanic crust as a mechanism to incorporate both 'undegassed' and 'degassed' ${ }^{3} \mathrm{He} /{ }^{4} \mathrm{He}$ signatures into the kimberlite source region. Subducted oceanic crust should have very low $\left(<8 \mathrm{R}_{\mathrm{A}}\right){ }^{3} \mathrm{He} /{ }^{4} \mathrm{He}$ (e.g., Moreira and Kurz, 2001). Although low ${ }^{3} \mathrm{He} /{ }^{4} \mathrm{He}$ compositions are observed in two kimberlite samples, the other three samples have variable and high $\left(18-27 \mathrm{R}_{\mathrm{A}}\right){ }^{3} \mathrm{He} /{ }^{4} \mathrm{He}$ compositions. Helium has a high diffusivity relative to incompatible trace elements: $D_{\mathrm{He}} \sim 10^{-10}-10^{-8} \mathrm{~cm}^{2} / \mathrm{s}$ in olivine and pyroxene, at $T=965-1170{ }^{\circ} \mathrm{C}$ (Trull and Kurz, 1993), compared to $D_{\mathrm{Nd}} \sim 10^{-17}-10^{-15} \mathrm{~cm}^{2} / \mathrm{s}$ in clinopyroxene at $T=1050$ $1300{ }^{\circ} \mathrm{C}$ (Van Orman et al., 2001). Thus, if low- ${ }^{3} \mathrm{He} /{ }^{4} \mathrm{He}$ subducted crust is stored in high $-{ }^{3} \mathrm{He} /{ }^{4} \mathrm{He}$ mantle, it will only retain its low- ${ }^{3} \mathrm{He} /{ }^{4} \mathrm{He}$ signature if the subducted crust domain is sufficiently large and storage time is sufficiently short (Hanyu and Kaneoka, 1997; Hanyu and Kaneoka, 1998). Thus, we propose that long storage times and variable amounts of diffusion result in the widely variable ${ }^{3} \mathrm{He} /{ }^{4} \mathrm{He}$ compositions preserved in the kimberlites today.

Many studies on trace element systematics in kimberlites have concluded that elevated trace element abundances in kimberlites are not consistent with a single-stage melting event of primitive garnet lherzolite (e.g., Mitchell, 1995), and therefore propose that kimberlites form from a stage of metasomatism, to enrich the kimberlite source in incompatible trace elements and volatiles, followed by a stage of melting, to produce the kimberlite magmas (e.g., Ringwood et al., 1992). As discussed in the preceding section, oceanic crust from which a small-degree melt was extracted in the subduction zone displays HFSE characteristics of kimberlites. After deep subduction and storage of this crust in the mantle, an additional event of small-degree melting of this crust generates a metasomatic melt that transfers the trace element characteristics of the subducted crust to local peridotitic mantle. This melting event, as well as subsequent melting of the fertilized peridotite, take place in the presence of residual garnet. These stages of garnet-residual melting (with large proportions of garnet involved in the first stage) produce the very steep HREE patterns characteristic of kimberlites, with depletion relative to primitive mantle in the heaviest REEs in some of the samples (Fig. 3).

The generation of metasomatic agents by very small degrees of melting of the subducted oceanic crust may also serve to enhance the negative $\Delta \varepsilon_{\mathrm{Hfi}}$ signature of the kimberlite source. Small-degree, disequilibrium melting has been proposed as a mechanism operating in the source of a MORB suite from the Mid-Atlantic Ridge north of Iceland that falls to the high- $\varepsilon_{\mathrm{Hf}}$ side of the mantle $\varepsilon_{\mathrm{Hf}}-\varepsilon_{\mathrm{Nd}}$ array. Blichert-Toft et al. (2005) suggested the possibility that these high $\varepsilon_{\mathrm{Hf}}$ values could result from disequilibrium melting of a garnet-bearing lithology in the mantle source. In this scenario, $\mathrm{Hf}$ is in isotopic disequilibrium among the various phases in the basalt source, because of the inferred very low diffusivity of Hf compared to REEs (Van Orman et al., 1998, 2001; Blichert-Toft et al., 2005). Thus, the Hf budget of the melt is dominated by the radiogenic Hf con- 
tained by garnet, which is preferentially consumed in the melting reaction at low pressures. Because the garnet stability field increases at greater pressures, small-degree melts of MORB-like bulk compositions at the high pressures inferred for kimberlite melting preferentially sample clinopyroxene rather than garnet (Yasuda et al., 1994; Kogiso et al., 2003; Dasgupta et al., 2006), and thus may be characterized by negative $\Delta \varepsilon_{\mathrm{Hfi}}$ values.

Arguments have been made for metasomatism of the kimberlite source occurring contemporaneously with the melting event that generates the kimberlites (Becker and le Roex, 2006), as well as for metasomatism occurring 100 s of m.y. to b.y. prior to kimberlite formation (Ringwood et al., 1992). However, metasomatized peridotites have been shown to develop very radiogenic $\varepsilon_{\mathrm{Hf}}$ in relatively short amounts of time $(<100$ m.y., Salters and Zindler, 1995). Because all of the kimberlites show negative $\Delta \varepsilon_{\mathrm{Hfi}}$ compositions, we infer that the metasomatic event must occur shortly before, or, possibly contemporaneously with, the melting event that gives rise to the kimberlite magma.

Although the processes proposed for the formation of the kimberlite source are similar to those proposed for formation of HIMU-type OIB mantle sources, the differences in composition between kimberlites and HIMU-type OIBs require some additional contrasts in the magma-generation processes. HIMU-source ancient oceanic crust may have subducted at a later stage in Earth's history, during a cooler mantle regime which would have led to dewatering of the slab, but not to melting during subduction. This could generate less-pronounced $\mathrm{Ta}-\mathrm{Nb}$ enrichments along with $\mathrm{Hf}-$ $\mathrm{Zr}$ enrichments in the HIMU mantle source relative to the kimberlite mantle source (Fig. 6). Alternatively (or additionally), HIMU-source subducted oceanic crust may physically mix in the solid state with plume-source mantle prior to or contemporaneously with ascent in the plume. This would serve to dilute, but not eradicate, the 'recycled' chemical signatures in the HIMU OIBs. Interestingly, one of the kimberlites with low ${ }^{3} \mathrm{He} /{ }^{4} \mathrm{He}$ (KIM 15) is most similar to HIMU in its HFSE compositions (Fig. 6), supporting a link to a HIMU-type source in the kimberlite source region, in addition to the 'undegassed' source.

\subsection{Implications for kimberlite mantle sources and mantle Hf-Nd mass balance}

West Greenland kimberlites erupt along the eastern margin of a province of ultramafic, alkaline magmatism that extends to the west throughout the Canadian Shield (Heaman et al., 2004; Tappe et al., 2006). Kimberlite magmatism in this province has occurred episodically from $\sim 1200$ to $\sim 45 \mathrm{Ma}$, including several episodes inferred to be related to the opening of the Iapetus Ocean (Heaman et al., 2004; Tappe et al., 2006). Although Hf-Nd isotopic data have been published for only a few kimberlite intrusions from this province (this study, Dowall et al., 2000; Schmidberger et al., 2002), at least some samples from each kimberlite intrusion show the negative $\Delta \varepsilon_{\mathrm{Hfi}}$ values that also characterize kimberlites from South Africa (Nowell et al., 2004). This suggests the possibility that this isotopic signature is characteristic of kimberlite mantle sources through- out the North Atlantic kimberlite provinces, or perhaps even globally.

It has been suggested previously that the kimberlite mantle source may represent a 'hidden mantle reservoir' apparently required by $\varepsilon_{\mathrm{Hf}}-\varepsilon_{\mathrm{Nd}}$ mantle-crust mass balance. The existence of this reservoir is indicated by the $\varepsilon_{\mathrm{Hf}}-\varepsilon_{\mathrm{Nd}}$ array of mantle-derived rocks, which falls above the $\varepsilon_{\mathrm{Hf}}-\varepsilon_{\mathrm{Nd}}$ composition of bulk silicate Earth, as determined from chondrites (Fig. 4; Blichert-Toft and Albarède, 1997). However, this inferred missing reservoir is based upon the assumption of a chondritic bulk silicate Earth. Boyet and Carlson $(2005,2006)$ showed that the mantle as sampled by a variety of magmas (including kimberlites) has had supra-chondritic $\mathrm{Sm} / \mathrm{Nd}$ since very early in Earth's history $(>4.53 \mathrm{Ga})$; whether $\mathrm{Lu} / \mathrm{Hf}$ of the mantle was different from chondritic at this time is unclear. However, constraining the $\mathrm{Lu} / \mathrm{Hf}$ ratio of the very early mantle requires, in part, accurately establishing the $\mathrm{Hf}$ isotopic mass balance of the various geochemical reservoirs in the crust and mantle. The kimberlites represent a distinctive mantle reservoir, characterized by negative $\Delta \varepsilon_{\mathrm{Hf}}$, that is not widely sampled by lavas that erupt at the Earth's surface. Thus it is important to establish the geographic extent and therefore the relative size of the kimberlite mantle source reservoir, and any relationship between the episodes of kimberlite magmatism in the Canadian and Greenland Shields and the isotopic evolution of kimberlite mantle sources. Although the limited data set precludes definitive answers to these issues, it is conceivable that the kimberlite mantle source is volumetrically underrepresented by magmas erupted and preserved at Earth's surface, and thus may play an important role in the $\varepsilon_{\mathrm{Hf}}-\varepsilon_{\mathrm{Nd}}$ mass balance of silicate Earth.

\section{CONCLUSIONS}

All analyzed West Greenland kimberlites have negative $\Delta \varepsilon_{\mathrm{Hfi}}$ compositions. This characteristic is shared by kimberlites from other geographic regions (South Africa, Canada), as well as by HIMU-type ocean island basalt. Tantalum$\mathrm{Nb}$ enrichments, $\mathrm{Hf}-\mathrm{Zr}$ depletions, and HREE depletions also characterize the West Greenland kimberlites. These trace element features are common in kimberlites from other regions, but are not typically observed in HIMU-type OIBs. Our favored model for kimberlite formation involves ancient subducted oceanic crust. We postulate that EMORB-type oceanic crust dewaters and partially melts as it subducts, and is stored in the mantle for lengths of time on the order of 1-3 b.y. Variable and high (6-27 $\left.\mathrm{R}_{\mathrm{A}}\right) \mathrm{He}$ isotopic compositions in the kimberlites are consistent with long periods of storage. Kimberlite magma generation begins with an episode of metasomatism, in which small-degree melts of the ancient oceanic crust transfer the trace element and isotopic signature of the subducted oceanic crust, along with subducted carbonate, to proximal 'primitive' or 'OIB-type' mantle peridotite. Disequilibrium melting during the generation of this metasomatic agent may further enhance the negative $\Delta \varepsilon_{\mathrm{Hfi}}$ values of the kimberlite source. The fertilized mantle peridotite subsequently melts to generate kimberlite magmas. The constancy of trace element and $\mathrm{Hf}-\mathrm{Nd}$ isotopic characteristics of kimberlites 
erupted globally suggests that the processes of kimberlite source formation and magma generation are reproducible on a large scale. All so-far analyzed kimberlites are consistent with the possibility that the kimberlite mantle source may provide mass-balance closure to the Earth's crustmantle system.

\section{ACKNOWLEDGMENTS}

We thank Philippe Telouk and Megan Kogut for keeping the mass spectrometers running smoothly. Helpful and constructive reviews were provided by L. Heaman and V. Salters. This work was supported by a Geological Society of America grant and a UWESS Graduate Research grant to A.M.G., support from INSU to J.B.T., NSF OCE 0116210 Grant to B.K.N., support from the Carlsberg Foundation and the Danish Natural Sciences Research Council to M.R., and a grant from the Institut Français pour la Recherche et la Technologie Polaires to F.A. A portion of the work by A.M.G. was performed under the auspices of the U.S. Department of Energy by the University of California, Lawrence Livermore National Laboratory under Contract No. W-7405-Eng-48.

\section{REFERENCES}

Amelin Y., Lee D.-C., Halliday A. N., and Pidgeon R. T. (1999) Nature of the Earth's earliest crust from hafnium isotopes in single detrital zircons. Nature 399, 252-255.

Barth M. G., Foley S. F., and Horn I. (2002a) Partial melting in Archean subduction zones; constraints from experimentally determined trace element partition coefficients between eclogitic minerals and tonalite melts under upper mantle conditions. Precambrian Res. 113, 323-340.

Barth M. G., Rudnick R. L., Horn I., McDonough W. F., Spicuzza M. J., Valley J. W., and Haggerty S. E. (2001) Geochemistry of xenolithic eclogites from West Africa; Part I, A link between low $\mathrm{MgO}$ eclogites and Archean crust formation. Geochim. Cosmochim. Acta 65, 1499-1527.

Barth M. G., Rudnick R. L., Horn I., McDonough W. F., Spicuzza M. J., Valley J. W., and Haggerty S. E. (2002b) Geochemistry of xenolithic eclogites from West Africa; Part 2, Origins of the high $\mathrm{MgO}$ eclogites. Geochim. Cosmochim. Acta 66, 4325-4345.

Becker M., and le Roex A. P. (2006) Geochemistry of South African on- and off-craton, Group I and Group II kimberlites: petrogenesis and source region evolution. J. Petrol. 47, 673-703.

Bizimis M., Salters V. J. M., and Dawson J. B. (2003) The brevity of carbonatite sources in the mantle: evidence from $\mathrm{Hf}$ isotopes. Contrib. Miner. Petr. 145, 281-300.

Bizzarro M., Simonetti A., Stevenson R. K., and David J. (2002) Hf isotope evidence for a hidden mantle reservoir. Geology 30, 771-774.

Blichert-Toft J. (2001) On the Lu-Hf isotope geochemistry of silicate rocks. Geostandard. Newslett. 25, 43-56.

Blichert-Toft J., Agranier A., Andres M., Kingsley R., Schilling J.-G., and Albarède F. (2005) Geochemical segmentation of the Mid-Atlantic Ridge north of Iceland and ridge-hot spot interaction in the North Atlantic. Geochem. Geophys. Geosyst. 6. doi: $10.1029 / 2004 \mathrm{GC} 00078$.

Blichert-Toft J., and Albarède F. (1997) The Lu-Hf isotope geochemistry of chondrites and the evolution of the mantlecrust system. Earth Planet. Sci. Lett. 148, 243-258.

Blichert-Toft J., Frey F. A., and Albarède F. (1999) Hf isotope evidence for pelagic sediments in the source of Hawaiian basalts. Science $\mathbf{2 8 5}$, 879-882.
Blichert-Toft J., Boyet M., Télouk P., and Albarède F. (2002) ${ }^{147} \mathrm{Sm} /{ }^{143} \mathrm{Nd}$ and ${ }^{176} \mathrm{Lu} /{ }^{176} \mathrm{Hf}$ in eucrites and the differentiation of the HED parent body. Earth Planet. Sci. Lett. 204, 167-181.

Blichert-Toft J., Chauvel C., and Albarède F. (1997) Separation of $\mathrm{Hf}$ and $\mathrm{Lu}$ for high-precision isotope analysis of rock samples by magnetic sector-multiple collector ICP-MS. Contrib. Miner. Petr. 127, 248-260.

Boyet M., and Carlson R. W. (2005) ${ }^{142} \mathrm{Nd}$ evidence for early $(>4.53 \mathrm{Ga})$ global differentiation of the silicate Earth. Science 309, 576-581.

Boyet M., and Carlson R. W. (2006) A new geochemical model for the Earth's mantle inferred from ${ }^{146} \mathrm{Sm}^{-142} \mathrm{Nd}$ systematics. Earth Planet. Sci. Lett. 250, 254-268.

Corgne A., Liebske C., Wood B. J., Rubie D. C., and Frost D. J. (2005) Silicate perovskite-melt partitioning of trace elements and geochemical signature of a deep perovskitic reservoir. Geochim. Cosmochim. Acta 69, 485-496.

Dasgupta R., Hirschmann M. M., and Stalker K. (2006) Immiscible transition from carbonate-rich to silicate-rich melts in the $3 \mathrm{GPa}$ melting interval of eclogite $+\mathrm{CO}_{2}$ and genesis of silicaundersaturated ocean island lavas. J. Petrol. 47, 647-671.

Dasgupta R., Hirschmann M. M., and Withers A. C. (2004) Deep global cycling of carbon constrained by the solidus of anhydrous, carbonated eclogite under upper mantle conditions. Earth Planet. Sci. Lett. 227, 73-85.

Dawson J. B. (1967). A review of the geology of kimberlite (ed. P. J. Wyllie). John Wiley, New York.

Dawson J. B. (1980) Kimberlites and their Xenoliths. SpringerVerlag, Berlin.

Day J. M. D., Hilton D. R., Pearson D. G., Macpherson C. G., Kjarsgaard B. A., and Janney P. E. (2005) Absence of a high time-integrated ${ }^{3} \mathrm{He} /(\mathrm{U}+\mathrm{Th})$ source in the mantle beneath continents. Geology 33, 733-736.

Defant M. J., and Drummond M. S. (1990) Derivation of some modern arc magmas by melting of young subducted lithosphere. Nature 347, 662-665.

Dowall D. P., Nowell G. M., Pearson D. G., Kjarsgaard B. A., and Carlson J. A. (2000) The nature of kimberlite source regions: a Hf-Nd isotope study of Slave Craton kimberlites. J. Conf. Abstr. 5, 357.

Dunai T. J., and Porcelli D. (2002) Storage and transport of noble gases in the subcontinental lithosphere. Rev. Mineral. Geochem. 47, 371-409.

Foley S. F., Barth M. G., and Jenner G. A. (2000) Rutile/melt partition coefficients for trace elements and an assessment of the influence of rutile on the trace element characteristics of subduction zone magmas. Geochim. Cosmochim. Acta 64, 933-938.

Haggerty S. E. (1994) Superkimberlites; a geodynamic diamond window to the Earth's core. Earth Planet. Sci. Lett. 122, 57-69.

Hammouda T. (2003) High-pressure melting of carbonated eclogite and experimental constraints on carbon recycling and storage in the mantle. Earth Planet. Sci. Lett. 214, 357-368.

Hanyu T., and Kaneoka I. (1997) The uniform and low ${ }^{3} \mathrm{He} /{ }^{4} \mathrm{He}$ ratios of HIMU basalts as evidence for their origin as recycled materials. Nature 390, 273-276.

Hanyu T., and Kaneoka I. (1998) Open system behavior of helium in case of the HIMU source areas. Geophys. Res. Lett. 25, 687690.

Harrison T. M., Blichert-Toft J., Muller W., Albarède F., Holden P., and Mojzsis S. J. (2005) Heterogeneous Hadean hafnium: evidence of continental crust by $4.5 \mathrm{Ga}$ ? Science 310, 1947 1950.

Heaman L. M., Kjarsgaard B. A., and Creaser R. A. (2004) The temporal evolution of North American kimberlites. Lithos 76, 377-397. 
Ionov D., Blichert-Toft J., and Weis D. (2005) Hf isotope compositions and HREE variations in off-craton garnet and spinel peridotite xenoliths from central Asia. Geochim. Cosmochim. Acta 69, 2399-2418.

Irifune, T., Hibberson, W. O., and Ringwood, A. E. (1989) Eclogite-garnetite transformation at high pressure and its bearing on the occurrence of garnet inclusions in diamond. In Special Publication-Geological Society of Australia (eds. J. Ross, A. L. Jaques, J. Ferguson, D. H. Green, S. Y. O'Reilly, R. V. Danchin and A. J. A. Janse, vol. 14.). pp. 877-882.

Janney P. E., Le Roex A. P., Carlson R. W., and Viljoen K. S. (2002) A chemical and multi-isotope study of the Western Cape olivine melilitite province, South Africa; implications for the sources of kimberlites and the origin of the HIMU signature in Africa. J. Petrol. 43, 2339-2370.

Johnson D. M., Hooper P. R., and Conrey R. M. (1999) XRF analysis of rocks and minerals for major and trace elements on a single low dilution Li-tetraborate fused bead. Adv. X-Ray Anal. 41, 843-867.

Kato T., Ohtani E., Ito Y., and Onuma K. (1996) Element partitioning between silicate perovskites and calcic ultrabasic melt. Phys. Earth Planet. Interiors 96, 201-207.

Kato T., Ringwood A. E., and Irifune T. (1988) Experimental determination of element partitioning between silicate perovskites, garnets and liquids: constraints on early differentiation of the mantle. Earth Planet. Sci. Lett. 89, 123-145.

Kinny P. D., Compston W., and Williams I. S. (1991) A reconnaissance ion-probe study of hafnium isotopes in zircons. Geochim. Cosmochim. Acta 55, 849-859.

Kogiso T., Hirschmann M. M., and Frost D. J. (2003) Highpressure partial melting of garnet pyroxenite: possible mafic lithologies in the source of ocean island basalts. Earth Planet. Sci. Lett. 216, 603-617.

Larsen L. M., and Rex D. C. (1992) A review of the 2500 Ma span of alkaline-ultramafic, potassic and carbonatitic magmatism in West Greenland. Lithos 28, 367-402.

Larsen L. M., Rex D. C., and Secher K. (1983) The age of carbonatites, kimberlites and lamprophyres from southern West Greenland: recurrent alkaline magmatism during 2500 million years. Lithos 16, 215-221.

Lassiter J. C., Blichert-Toft J., Hauri E. H., and Barsczus H. G. (2003) Isotope and trace element variations in lavas from Raivavae and Rapa, Cook-Austral islands: constraints in the nature of HIMU- and EM-mantle and the origin of mid-plate volcanism in French Polynesia. Chem. Geol. 202, 115-138.

le Roex A. P. (1986) Geochemical correlation between Southern African kimberlites and South Atlantic hotspots. Nature 324, 243-245.

le Roex A. P., Bell D. R., and Davis P. (2003) Petrogenesis of group I kimberlites from Kimberley, South Africa: evidence from bulk-rock geochemistry. J. Petrol. 44, 2261-2286.

Leybourne M. I., Van Wagoner N., and Ayres L. D. (1999) Partial melting of a refractory subducted slab in a Paleoproterozoic island arc; implications for global chemical cycles. Geology 27, 731-734.

Mitchell R. H. (1986). Kimberlites; Mineralogy, Geochemistry, and Petrology. Plenum Press, New York.

Mitchell R. H. (1995) Kimberlites, Orangeites, and Related Rocks. Plenum Press, New York.

Moore R. O., and Gurney J. J. (1985) Pyroxene solid solution in garnets included in diamond. Nature 318, 553-555.

Moreira M., and Kurz M. D. (2001) Subducted oceanic lithosphere and the origin of the 'high $\mu$ ' basalt helium isotopic signature. Earth Planet. Sci. Lett. 189, 49-57.

Nelson B. K. (1995) Fluid flow in subduction zones: evidence from neodymium and strontium isotope variations in metabasalts of the Franciscan Complex, California. Contrib. Miner. Petr. 119, $247-262$.

Nelson B. K., and Blichert-Toft J. (2004) Origin of moderate HIMU source in the Canary Islands: new limits from Nd-Hf$\mathrm{Sr}-\mathrm{Pb}$ isotope data. Geochim. Cosmochim. Acta 68, A572.

Nelson D. R. (1989) Isotopic characteristics and petrogenesis of the lamproites and kimberlites of central West Greenland. Lithos 22, 265-274.

Nielsen, T. F. D., and Jensen, S. M. (2005) The Majuagaa calcitekimberlite dyke, Maniitsoq, southern West Greenland. Geological Survey of Denmark and Greenland, Report 2005/43, 59 p.

Nowell G. M., Pearson D. G., Bell D. R., Carlson R. W., Smith C. B., Kempton P. D., and Noble S. R. (2004) Hf isotope systematics of kimberlites and their megacrysts; new constraints on their source regions. J. Petrol. 45, 1583-1612.

O'Brien H. E., and Tyni M. (1998) Mineralogy and geochemistry of kimberlites and related rocks from Finland. Seventh International Kimberlite Conference, 625-636.

Poli S., and Schmidt M. W. (1995) $\mathrm{H}_{2} \mathrm{O}$ transport and release in subduction zones; experimental constraints on basaltic and andesitic systems. J. Geophys. Res. 100, 22299-22314.

Ringwood A. E. (1990) Slab-mantle interactions. Chem. Geol. 82, 187-207.

Ringwood A. E., Kesson S. E., Hibberson W., and Ware N. (1992) Origin of kimberlites and related magmas. Earth Planet. Sci. Lett. 113, 521-538.

Salters V. J., and Zindler A. (1995) Extreme ${ }^{176} \mathrm{Hf} /{ }^{177} \mathrm{Hf}$ in the suboceanic mantle. Earth Planet. Sci. Lett. 129, 13-30.

Salters V. J. M., and White W. M. (1998) Hf isotope constraints on mantle evolution. Chem. Geol. 145, 447-460.

Schmidberger S. S., Simonetti A., and Francis D. (2001) Sr-Nd-Pb isotope systematics of mantle xenoliths from Somerset Island kimberlites: evidence for lithosphere stratification beneath Arctic Canada. Geochim. Cosmochim. Acta 65, 4243-4255.

Schmidberger S. S., Simonetti A., Francis D., and Gariepy C. (2002) Probing Archean lithosphere using the $\mathrm{Lu}-\mathrm{Hf}$ isotope systematics of peridotite xenoliths from Somerset Island kimberlites, Canada. Earth Planet. Sci. Lett. 197, 245-259.

Schmidt M. W., and Poli S. (1998) Experimentally based water budgets for dehydrating slabs and consequences for arc magma generation. Earth Planet. Sci. Lett. 163, 361-379.

Scott B. H. (1981) Kimberlite and lamproite dykes from Holsteinsborg, West Greenland. Meddelelser om Gronland. Geoscience 4, 24.

Scott Smith, B. H. (1987) Greenland. In Mantle Xenoliths (ed. P. H. Nixon).

Sharp W. E. (1974) A plate tectonic origin for diamond-bearing kimberlites. Earth Planet. Sci. Lett. 21, 351-354.

Smith C. B. (1983) Pb, Sr and $\mathrm{Nd}$ isotopic evidence for sources of southern African Cretaceous kimberlites. Nature 304, 51-54.

Spriggs, A. J. (1988) A geochemical and isotopic study of kimberlites from Namibia. Ph.D., University of Leeds.

Stalder R., Foley S. F., Brey G. P., and Horn I. (1998) Mineralaqueous fluid partitioning of trace elements at 900-1200 degrees $\mathrm{C}$ and 3.0-5.7 GPa; new experimental data for garnet, clinopyroxene, and rutile, and implications for mantle metasomatism. Geochim. Cosmochim. Acta 62, 1781-1801.

Sun S.-s., and McDonough W.F. (1989) Chemical and isotopic systematics of oceanic basalts: implications for mantle composition and processes. In Magmatism in the Ocean Basins (eds. A. D. Saunders and M. J. Norry, vol. 42.). The Geological Society, pp. 313-345.

Tachibana Y., Kaneoka I., Gaffney A., and Upton B. (2006) Ocean-island basalt-like source of kimberlite magmas from West Greenland revealed by high ${ }^{3} \mathrm{He} /{ }^{4} \mathrm{He}$ ratios. Geology 34, 273-276. 
Tappe S., Foley S. F., Jenner G. A., Heaman L. M., Kjarsgaard B. A., Romer R. L., Stracke A., Joyce N., and Hoefs J. (2006) Genesis of ultramafic lamprophyres and carbonatites at Aillik Bay, Labrador: a consequence of incipient lithospheric thinning beneath the North Atlantic Craton. J. Petrol. 47, 1261-1315.

Trull T. W., and Kurz M. D. (1993) Experimental measurements of ${ }^{3} \mathrm{He}$ and ${ }^{4} \mathrm{He}$ mobility in olivine and clinopyroxene at magmatic temperatures. Geochim. Cosmochim. Acta 57, 1313-1324.

van Gool J. A. M., Connelly J. N., Marker M., and Mengel F. C. (2002) The Nagssugtoqidian Orogen of West Greenland: tectonic evolution and regional correlations from a West Greenland perspective. Can. J. Earth Sci. 39, 665-686.

Van Orman J. A., Grove T. L., and Shimizu N. (1998) Uranium and thorium diffusion in diopside. Earth Planet. Sci. Lett. 160, 505-519.

Van Orman J. A., Grove T. L., and Shimizu N. (2001) Rare earth element diffusion in diopside; influence of temperature, pressure, and ionic radius, and an elastic model for diffusion in silicates. Contrib. Mineral. Petrol. 141, 687-703.

Vervoort J. D., and Blichert-Toft J. (1999) Evolution of the depleted mantle: Hf isotope evidence from juvenile rocks through time. Geochim. Cosmochim. Acta 63, 533-566.
Vervoort J. D., Patchett P. J., Blichert-Toft J., and Albarède F. (1999) Relationships between $\mathrm{Lu}-\mathrm{Hf}$ and $\mathrm{Sm}-\mathrm{Nd}$ isotopic systems in the global sedimentary system. Earth Planet. Sci. Lett. 168, 79-99.

Willbold M., and Stracke A. (2006) Trace element composition of mantle end-members: implications for recycling of oceanic upper and lower continental crust. Geochem. Geophys. Geosyst. 7. doi:10.1029/2005GC00100.

Xiong X. L., Adam J., and Green T. H. (2005) Rutile stability and rutile/melt HFSE partitioning during partial melting of hydrous basalt; implications for TTG genesis. Chem. Geol. 218, 339-359.

Yasuda A., Fujii T., and Kurita K. (1994) Melting phase relations of an anhydrous mid-ocean ridge basalt from 3 to $20 \mathrm{GPa}$; implications for the behavior of subducted oceanic crust in the mantle. J. Geophys. Res. 99, 9401-9414.

Yaxley G. M., and Green D. H. (1994) Experimental demonstration of refractory carbonate-bearing eclogite and siliceous melt in the subduction regime. Earth Planet. Sci. Lett. 128, 313-325.

Associate editor: Richard J. Walker 